\title{
Workflow for Using Unmanned Aircraft Systems and Traditional Geospatial Data to Delineate Agricultural Drainage Tiles at Edge-of-Field Sites
}

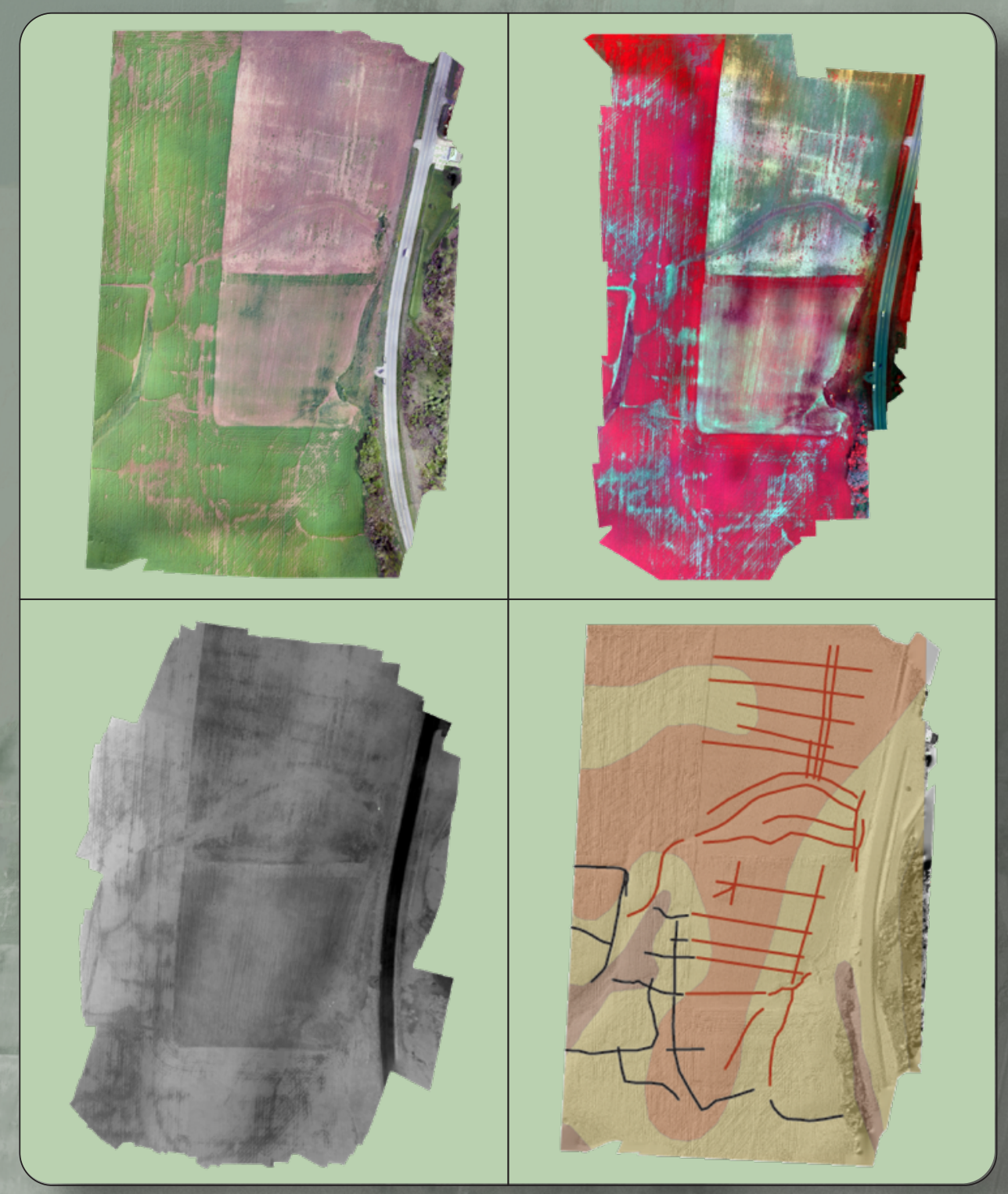

Scientific Investigations Report 2021-5013 
Cover. Modified figure 8 of this report: Top-left shows visible color image; top-right shows multispectral image; bottom-left shows thermal infrared image; bottom-right shows tiles from data collected from Wisconsin Surface-Water 3 and 4 in spring of 2019. 


\section{Workflow for Using Unmanned Aircraft Systems and Traditional Geospatial Data to Delineate Agricultural Drainage Tiles at Edge-of-Field Sites}

By J. Jeremy Webber and Tanja N. Williamson

Scientific Investigations Report 2021-5013 


\section{U.S. Geological Survey, Reston, Virginia: 2021}

For more information on the USGS - the Federal source for science about the Earth, its natural and living resources, natural hazards, and the environment—visit https://www.usgs.gov or call 1-888-ASK-USGS.

For an overview of USGS information products, including maps, imagery, and publications, visit https://store.usgs.gov/.

Any use of trade, firm, or product names is for descriptive purposes only and does not imply endorsement by the U.S. Government.

Although this information product, for the most part, is in the public domain, it also may contain copyrighted materials as noted in the text. Permission to reproduce copyrighted items must be secured from the copyright owner.

Suggested citation:

Webber, J.J., and Williamson, T.N., 2021, Workflow for using unmanned aircraft systems and traditional geospatial data to delineate agricultural drainage tiles at edge-of-field sites: U.S. Geological Survey Scientific Investigations Report 2021-5013, 18 p., https://doi.org/10.3133/sir20215013.

Associated data:

Williamson, T.N., Webber, J.J., and Hoefling, D.J., 2021a, Low-altitude visible, multispectral, and thermal-infrared imagery from edge-of-field monitoring sites for Great Lakes Restoration Initiative-Michigan Flume 2: U.S. Geological Survey data release, https://doi.org/10.5066/P9EXXX20.

Williamson, T.N., Webber, J.J., and Hoefling, D.J., 2021b, Low-altitude visible, multispectral, and thermal-infrared imagery from edge-of-field monitoring sites for Great Lakes Restoration Initiative-Wisconsin Surface Water 3: U.S. Geological Survey data release, https://doi.org/10.5066/P9N8ELYZ.

Williamson, T.N., Webber, J.J., and Hoefling, D.J., 2021c, Low-altitude visible, multispectral, and thermal-infrared imagery from edge-of-field monitoring sites for Great Lakes Restoration Initiative-Wisconsin Surface Water 4 and 5 : U.S. Geological Survey data release, https://doi.org/10.5066/P9DNURMT.

Williamson, T.N., Webber, J.J., and Hoefling, D.J., 2021d, Low-altitude visible, multispectral, and thermal-infrared imagery from edge-of-field monitoring sites for Great Lakes Restoration Initiative - Wisconsin Bioreactor: U.S. Geological Survey data release, https://doi.org/10.5066/P93R270D.

ISSN 2328-0328 (online) 


\section{Acknowledgments}

This research was conducted in cooperation with the Great Lakes Restoration Initiative. We appreciate the assistance of site leads and personnel in preparing for this data-collection effort. The National Unmanned Aircraft Systems Program Office also provided technical support throughout the process. Finally, we appreciate the help of colleagues and U.S. Geological Survey peer reviewers whose comments helped to improve this product. 



\section{Contents}

Acknowledgments ……...................................................................................................................

Abstract

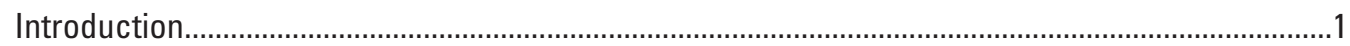

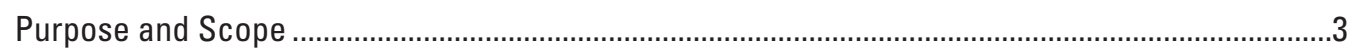

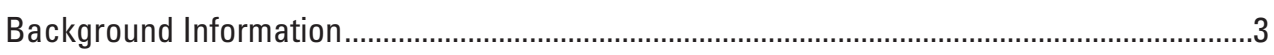

UAS Data Collection and Photogrammetry Methods …….......................................................

Sensors, Mission Planning, and Data Capture ……..............................................................

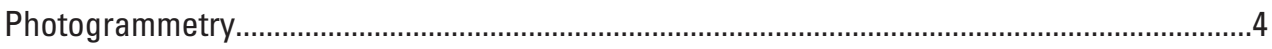

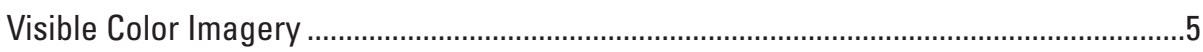

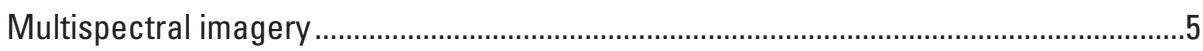

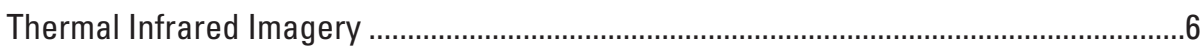

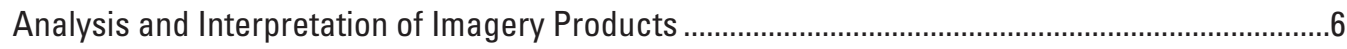

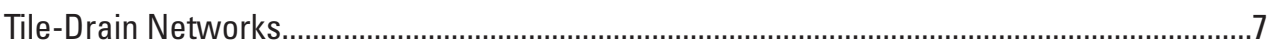

Contributing Area for Edge-of-Field Monitoring ......................................................................

Surface-Water Flow Paths ............................................................................................

Site-specific Information Provided by UAS Surveys ……............................................................

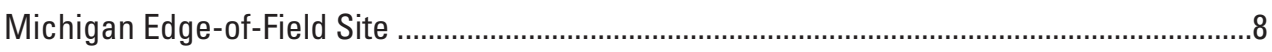

Wisconsin Edge-of-Monitoring Sites ............................................................................ 11

Wisconsin Surface Water 3 and Tile 1 ........................................................................

Wisconsin Surface-Water Sites 4 and 5................................................................

Wisconsin Bioreactor ………………..........................................................................

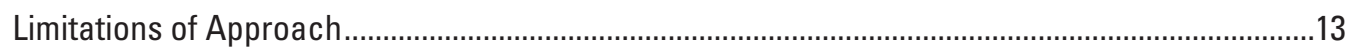

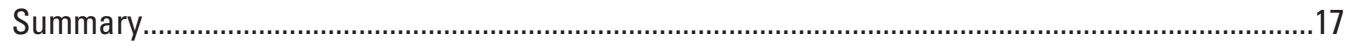

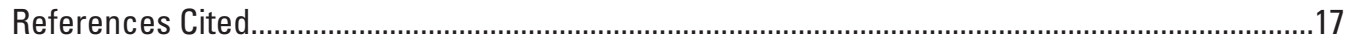

\section{Figures}

1. Figure showing regional map of Great Lakes Restoration Initiative edge-of-field sites.........................................................................................................

2. Graphic showing structure-from-motion workflow with details of

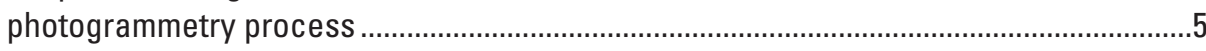

3. Figure showing multispectral imagery showing, $A$, field with cover crop and, $B$, field without cover crop ................................................................................

4. Graphic showing edge-of-field site data-analysis workflow highlighting products and process for tile delineation.

5. Graphic showing surface hydrology delineation workflow in perspective

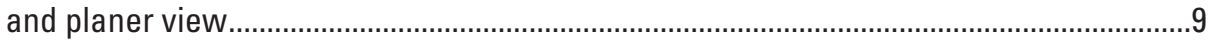

6. Figure showing Michigan flume 2 and tile-drain 2 imagery, surface model, and interpreted surface-water flow paths and tile-drain locations.

7. Figure showing Wisconsin surface-water 3 and tile-drain 1 imagery, surface model, and interpreted surface-water flow paths and tile-drain locations.

8. Figure showing Wisconsin surface water 4 and 5 imagery, digital surface model, and interpreted surface flow paths and tile-drain locations. 
9. Figure showing Wisconsin bioreactor site features.

10. Figure showing Wisconsin bioreactor imagery, surface model, and interpreted surface-water flow paths and tile-drain locations.

\section{Tables}

1. Cameras and imagery types used in unmanned aircraft systems work at edge-of-field sites.

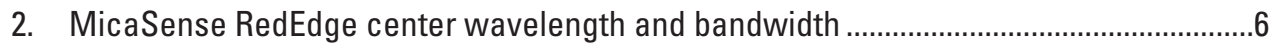

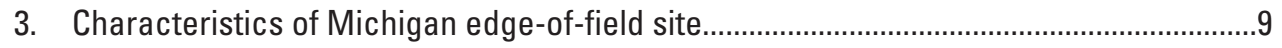

4. Characteristics of Wisconsin surface-water 3 and tile drain $1 \ldots \ldots \ldots \ldots \ldots \ldots \ldots \ldots \ldots \ldots \ldots \ldots \ldots . . .13$

5. Characteristics of Wisconsin surface-water sites 4 and $5 \ldots \ldots \ldots \ldots \ldots \ldots \ldots \ldots \ldots \ldots \ldots \ldots \ldots \ldots \ldots . . . . .15$

\section{Conversion Factors}

U.S. customary units to International System of Units

\begin{tabular}{|c|c|c|}
\hline Multiply & By & To obtain \\
\hline \multicolumn{3}{|c|}{ Length } \\
\hline centimeter $(\mathrm{cm})$ & 0.3937 & inch (in.) \\
\hline millimeter (mm) & 0.03937 & inch (in.) \\
\hline meter (m) & 3.281 & foot $(\mathrm{ft})$ \\
\hline kilometer (km) & 0.6214 & mile (mi) \\
\hline kilometer (km) & 0.5400 & mile, nautical (nmi) \\
\hline meter $(\mathrm{m})$ & 1.094 & yard (yd) \\
\hline \multicolumn{3}{|c|}{ Area } \\
\hline square meter $\left(\mathrm{m}^{2}\right)$ & 0.0002471 & acre \\
\hline hectare (ha) & 2.471 & acre \\
\hline square hectometer $\left(\mathrm{hm}^{2}\right)$ & 2.471 & acre \\
\hline square kilometer $\left(\mathrm{km}^{2}\right)$ & 247.1 & acre \\
\hline square centimeter $\left(\mathrm{cm}^{2}\right)$ & 0.001076 & square foot $\left(\mathrm{ft}^{2}\right)$ \\
\hline square meter $\left(\mathrm{m}^{2}\right)$ & 10.76 & square foot $\left(\mathrm{ft}^{2}\right)$ \\
\hline square centimeter $\left(\mathrm{cm}^{2}\right)$ & 0.1550 & square inch $\left(\mathrm{ft}^{2}\right)$ \\
\hline square hectometer $\left(\mathrm{hm}^{2}\right)$ & 0.003861 & section ( 640 acres or 1 square mile) \\
\hline hectare (ha) & 0.003861 & square mile $\left(\mathrm{mi}^{2}\right)$ \\
\hline square kilometer $\left(\mathrm{km}^{2}\right)$ & 0.3861 & square mile $\left(\mathrm{mi}^{2}\right)$ \\
\hline
\end{tabular}

Temperature in degrees Celsius $\left({ }^{\circ} \mathrm{C}\right)$ may be converted to degrees Fahrenheit $\left({ }^{\circ} \mathrm{F}\right)$ as follows:

$$
{ }^{\circ} \mathrm{F}=\left(1.8 \times{ }^{\circ} \mathrm{C}\right)+32 .
$$




\section{Datum}

Horizontal coordinate information is referenced to the North American Datum of 1983 (NAD 83).

Vertical coordinate information is referenced to the North American Vertical Datum of 1988 (NAVD 88).

Altitude, as used in this report, refers to distance above the vertical datum.

\section{Abbreviations}

$\begin{array}{ll}\text { AOI } & \text { area of interest } \\ \text { BMP } & \text { best management practice } \\ \text { DEM } & \text { digital elevation model } \\ \text { DSM } & \text { digital surface model } \\ \text { EOF } & \text { edge of field } \\ \text { GSD } & \text { ground sampling distance } \\ \text { GLRI } & \text { Great Lakes Research Initiative } \\ \text { lidar } & \text { light detection and ranging } \\ \text { TIR } & \text { thermal infrared } \\ \text { NIR } & \text { near infrared } \\ \text { MI-FM2 } & \text { Michigan flume 2 } \\ \text { MS } & \text { multispectral } \\ R_{\text {edge }} & \text { RedEdge } \\ \text { UAS } & \text { unmanned aircraft system } \\ \text { USGS } & \text { U.S. Geological Survey } \\ \text { Vis-C } & \text { visible color } \\ \text { WI-SW3 } & \text { Wisconsin surface-water 3 } \\ \text { WI-SW4 } & \text { Wisconsin surface-water 4 } \\ \text { WI-SW5 } & \text { Wisconsin surface-water 5 }\end{array}$





\title{
Workflow for Using Unmanned Aircraft Systems and Traditional Geospatial Data to Delineate Agricultural Drainage Tiles at Edge-of-Field Sites
}

\author{
By J. Jeremy Webber and Tanja N. Williamson
}

\section{Abstract}

Managing nutrient and sediment runoff from fields that drain to the Great Lakes is key to mitigating harmful algal blooms. Implementation of best management practices on agricultural land is considered a critical step to improving water quality in these streams, however the effect of these best management practices is difficult to quantify. The purpose of this study was to use a suite of high-resolution imagery acquired with unmanned aircraft systems (including a combination of visible, multispectral, and thermal cameras) to better characterize edge-of-field (EOF) sites in Michigan and Wisconsin that are monitored in cooperation with the Great Lakes Restoration Initiative. This high-resolution imagery (2.5-12-centimeter ground resolution) was used to delineate artificial subsurface drainage (tile-drain) networks and surface water flow paths that indicate contributing areas (that is, all area that drains to a monitored point) at these EOF sites, providing better characterization of each study site. Contributing areas for these sites ranged from 2.86 to 5.07 hectares and, among the sites, tile drains were identified as those that followed soil properties and those that were more densely patterned networks. These surveys also indicated that the contributing area monitored at the EOF sites may cross field boundaries and is not always coincident with the area underlain by subsurface drainage.

\section{Introduction}

As part of the Great Lakes Restoration Initiative research (GLRI), cropland sites are being monitored by the U.S. Geological Survey (USGS) in multiple states across several environmental settings to quantify the effect of individual best management practices (BMPs) on water quality that has been linked with harmful algal blooms (Baker and others, 2019). At each of these cropland sites, surface runoff (overland flow) from cropland is being monitored at the edge of field (EOF) as BMPs are implemented (for example, a combination of reduced tillage and cover crops), by quantifying and sampling runoff as it leaves the field. Most of these EOF sites are known to have, or suspected of having, artificial subsurface drainage (tile drains) as well. However, even at those sites where tile-drain discharge is included with EOF monitoring of known outlets, information on the expanse and characteristics of tile drains is minimal. A key goal for these monitoring sites is an accounting of nutrient and sediment yields as a function of the area being monitored, including overland flow and tile-drain discharge. Lead investigators at many of these sites identified the lack of information about subsurface drainage as a critical need that prevented an accurate accounting of runoff and nutrient budgets. At paired EOF sites in northeastern Indiana (fig. 1; surface water [tile drain] $1 \& 2$, USGS Site IDs 411229084541101[2] and 411228084541701[2] in the western Lake Erie Basin; U.S. Geological Survey, 2021), unmanned aircraft systems (UAS) were successfully used to map tile drains in response to ongoing questions about differences in water quality and quantity from adjacent monitored fields, specifically whether these differences were related to tile-drain density and connectivity (Williamson and others, 2019). Tile-drain mapping was then extended to the Ohio GLRI EOF site (fig. 1; Allred and others, 2020) where surface water and tile-drain discharge were also monitored (fig. 1; USGS Site ID 405051083391201[2]; U.S. Geological Survey, 2021). For each site, a suite of UAS imagery, at a range of ground sampling distances (GSD; approximately $2-13$ centimeters $[\mathrm{cm}])$, was key to discerning the full extent of the tile network and identifying areas where discontinuities in the tile-drain network may be contributing to water-quality and field-management issues.

Tile-drain systems have been widely installed into poorly drained agricultural soils as a water-management technique since the 1800s, with the goal of earlier access to and better management of fields during wet conditions (Gökkaya and others, 2017). Agriculture in the U.S. Midwest - including Illinois, Indiana, Iowa, Michigan, Minnesota, and Ohiogenerally benefits from this artificial drainage because it increases yields and expands the area suitable for farming (Gökkaya and others, 2017). In Illinois, Indiana, Iowa, Ohio, and Michigan 70-90 percent of all drained land is cropland, and in Indiana and Ohio 50 percent of all cropland is drained (Zucker and Brown, 1998). Tile drains are an 


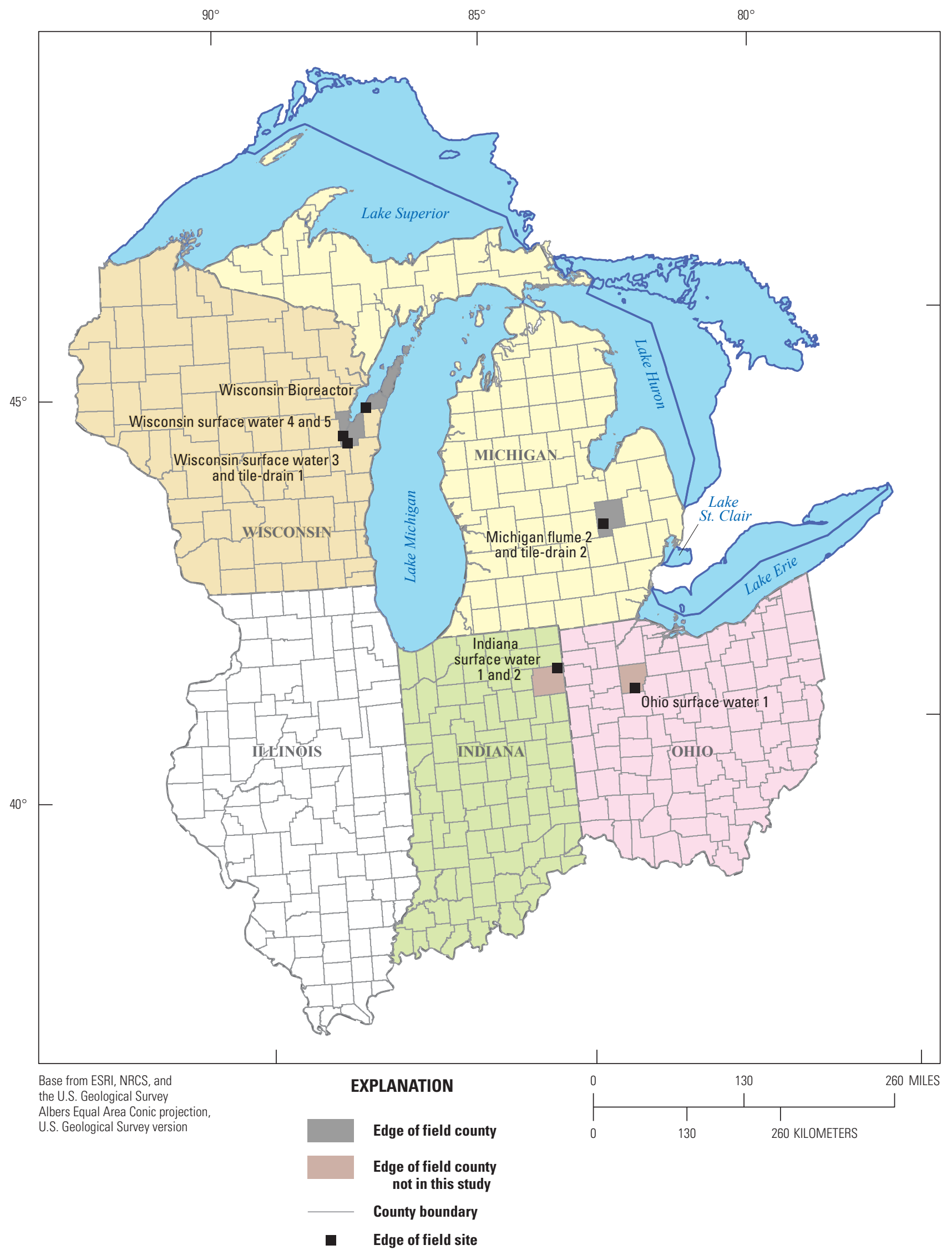

Figure 1. Regional map of Great Lakes Restoration Initiative edge-of-field sites. Counties referenced in text are highlighted in gray. 
informal, aerially extensive management practice but are not a designated BMP. Tile drains can act as a direct path for surface-applied nutrients and eroded soil to streams, and can alter groundwater recharge, stormflow, and base flow (Schilling and Helmers, 2008; Lemke and others, 2011; Red River Retention Authority-Basin Technical and Scientific Advisory Committee, 2011; Schottler and others, 2014). Original tile-drain systems consisted of interlocking clay pipes entrenched where water ponded on a field - usually a combination of a topographic low and a poorly drained soil (referred to here as topographic-soil tile drains). More modern systems use corrugated plastic and parallel lines that intersect a "main" drain, resulting in a higher density of tile drainage (that is, length of tile per area of field), and frequently span the entire field, not just the poorly drained locations. Because of the timespan during which tile drains have been used, combined with the fact that they are privately installed and maintained, the condition, distribution, and connectivity of tile drainage to surface water systems is only generally known. Many property owners do not know the location, age, or condition of their own tile network; frequently, only an outlet has been identified.

\section{Purpose and Scope}

The purpose of this report is to describe a workflow for using UAS and traditional geospatial data to delineate agricultural drainage tiles at EOF sites, each of which is monitored in cooperation with GLRI. Tile-drainage networks at EOF sites with known or suspected tile-drain systems were delineated using high-resolution digital surface models (DSMs) and orthophotos in visible-color (Vis-C; red-green-blue as a single band), multispectral (MS; independent bands of blue, green, red, red-edge $\left[\mathrm{R}_{\text {edge }}\right]$, and near infrared [NIR]), and long-wave, thermal-infrared (TIR) spectra.

During spring 2019, four EOF sites were flown with UAS, including two quadcopters and a suite of cameras. The study area for this project consists of one site in Michigan and three sites in Wisconsin (fig. 1). The Michigan site is in Genesee County and ultimately drains to Lake Huron. Two of the Wisconsin sites are in southwestern Brown County and the other is in southwestern Door County; all are part of stream systems that drain to Green Bay and Lake Michigan.

This data collection was modeled after that at the Indiana EOF site, flown in spring 2017 (Williamson and others, 2019). Collection dates targeted days after large rainstorms, beginning in late April, because this previous work showed the importance of relatively high soil-water content combined with sunny conditions to successful drainage-tile identification. When possible, the area flown extended beyond the already identified field boundaries to best capture the entire tile-drain network and provide a record of site conditions. In general, these sites were smaller than 50 acres, making it possible to capture imagery with all three cameras in a single field day.

\section{Background Information}

Before intensive UAS surveys were conducted, satellite imagery for each GLRI edge-of-field site was investigated to determine whether these data could provide the same information as what had been provided by targeted UAS data collection at the Indiana and Ohio GLRI sites (fig. 1). While some aspects of the tile-drain network were recognizable in satellite imagery from those sites, satellite imagery did not provide the detail needed to thoroughly determine the extent and location of tile at each site. Drawbacks to satellite imagery included:

1. highest resolution imagery (30-65-cm GSD) was an order of magnitude coarser than that available from UAS products and was usually only in panchromatic (single wavelength) spectra;

2. it was difficult to distinguish sites with tile from those with soils that reflected surface-flow paths, and there was indication of tile drainage for at least one site where no tiles were known to exist; and

3. it was difficult to target specific field conditions (for example, immediately after precipitation events) with satellite imagery (Allred and others, 2020). Satellites scan the same section of the earth on a daily to biweekly basis, but analysis is dependent on acquisition of a cloud-free scene.

In contrast, the suite of contemporaneous UAS imagery and finer GSD made interpretation across field sites more consistent and targeted. With UAS, the conditions and timing for remote sensing can be planned around field conditions and the finer GSD from UAS imagery enables one to discern features that may go undetected in satellite imagery. Finally, satellite imagery is rarely available with the overlap necessary to create a DSM, and the DSM generated from UAS imagery provides additional information about topography and farm management that is not provided by most available digital elevation models (DEMs) which may have a GSD greater than 1 meter (m).

Consequently, UAS data collection was identified as a more comprehensive method for delineating tile-drain extent and providing site leads with consistent information about individual sites. The more complete representation of tile-drain networks discerned from these detailed surveys may 
also provide a means of identifying portions of the network which are not functioning properly based on appearance of the network in contemporaneous UAS imagery and repeat satellite imagery. This provides agricultural producers a new method to effectively manage fields and to better protect water resources and corresponds to the improved-management goals of GLRI.

\section{UAS Data Collection and Photogrammetry Methods}

For each site, a series of UAS low-altitude imagery was collected with the intention of providing a suite of Vis-C, MS, and TIR imagery (table 1) for the area of interest (AOI). All flights were planned for a 92-m flight altitude with a 2-second image-capture interval and image overlap of approximately 75 percent between sequential images and 50-60 percent between adjacent flight lines. This consistently provided for "stereo" coverage of each AOI, enabled photogrammetric analysis, and minimized missing data, blurred areas, and inconsistent accuracy in interpretation (Matthews and others, 2016). The resulting imagery and products had GSDs of $2.4-12 \mathrm{~cm}$ among the image types, reflecting the pixel size for each.

\section{Sensors, Mission Planning, and Data Capture}

Flight planning was done in ArduPilot Mission

Planner 1.3 to best manage overlap between sequential photos and among individual flight lines; to maintain flight speeds that were specific to the needs of each camera (table 1); and to ensure that the entire flight area was covered while minimizing any image-capture beyond the intended agricultural fields. Each UAS plan was communicated to landowners before sites were flown (in coordination with site leads) and was flown according to Department of the Interior UAS specifications (Operational Procedures Memorandum (OPM)-11; U.S. Department of Interior, 2021). Adjacent property owners and local law enforcement were also informed.
Sensors were flown suspended from 3DR Solo quadcopters and flight plans were transferred to the Tower ground-control station application (www.3DR.com), which enables a single UAS pilot to implement a preplanned flight, monitor telemetry and progress, and return to manual flight conditions if necessary. When possible, all cameras were flown on a single day to have as consistent field conditions as possible, usually with Vis-C in the morning, TIR at midday (close to noon), and MS in the afternoon. As conditions allowed, 5 to 10 AeroPoint (https://www.propelle raero.com/aeropoints/) ground control stations were placed around the AOI to quantify and (or) minimize the horizontal and vertical error in each orthophoto and DSM when images were processed.

Successful data capture was verified before leaving a site, using a combination of the number of images captured, low-resolution alignment of non-georeferenced images based on pixel matching (Vis-C), and plotting of georeferenced MS and TIR camera locations.

\section{Photogrammetry}

Structure-from-motion photogrammetry is the process of taking multiple images and stitching them into a single uniform-scale image, an orthophoto, through the matching of individual pixels (Westoby and others, 2012). After returning from the field, extraneous images from take-off and landing sequences were removed because field of view changes rapidly between these successive images. Blurry images, which can occur when a gust of wind blows during image capture or when the aircraft turns to fly another transect, were also removed. Each set of images was then processed in Agisoft Metashape 1.5.2 (formerly known as Photoscan) following a set workflow (fig. 2) that was developed in coordination with the USGS National UAS Program Office and incorporates the workflow of Matthews and others (2016). Photos were aligned with a matching-point limit of 60,000, retaining all initial tie points, without adaptive fitting, and using default optimization parameters. Reconstruction uncertainty was gradually reduced to a goal of 10 pixels ( 15 for TIR) and optimized with default parameters. Projection accuracy was gradually reduced to a goal of 2 to 3 pixels ( 4 to 6 for

Table 1. Cameras and imagery types used in unmanned aircraft systems work at edge-of-field sites.

[cm, centimeter; $\mathrm{m} / \mathrm{s}$, meter per second]

\begin{tabular}{llcc}
\hline \multicolumn{1}{c}{ Imagery type } & \multicolumn{1}{c}{ Camera } & Ground sampling distance (cm) & Flight speed (m/s) \\
\hline Visible color & Ricoh GRII & 2.5 & 9 \\
Multispectral & MicaSense RedEdge 3 & 6 & 7 \\
Thermal infrared & FLIR Vue Pro R & 12 & 5 \\
\hline
\end{tabular}




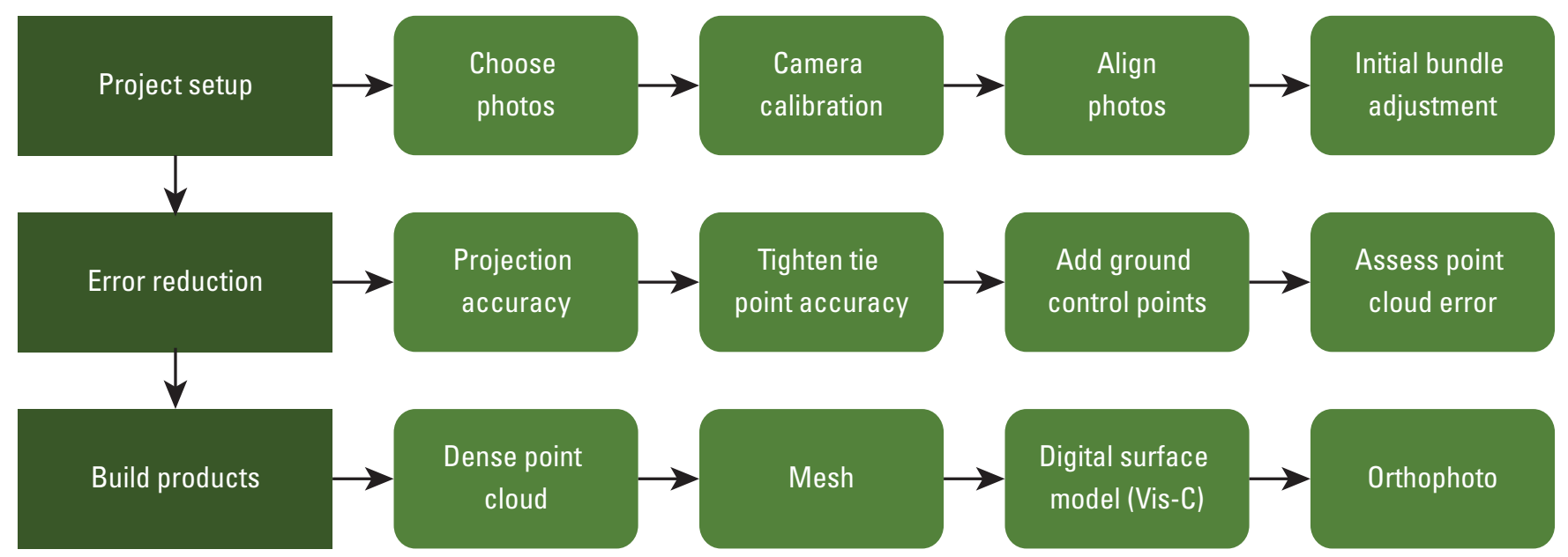

Figure 2. Structure-from-motion workflow with details of photogrammetry process.

TIR) and optimized with default parameters for multispectral and TIR and all parameters for visible imagery. Because these sites were generally flat or gently sloping, spatial accuracy of the resultant Vis-C orthophotos at sites where field conditions allowed for use of ground control ranged from 1 to $3 \mathrm{~cm}$ horizontally and 1.5 to $6 \mathrm{~cm}$ vertically; at the Wisconsin Surface Water 3 site, where site relief exceeded $8 \mathrm{~m}$, vertical accuracy was $17 \mathrm{~cm}$.

This workflow provided the orthophotos (in a TIFF format) for each type of imagery in addition to the DSM (also a TIFF) from Vis-C imagery. Orthophotos and DSMs were analyzed in ArcGIS (10.7) geographic information systems software to compare UAS products. This also enabled upscaling from the $2.5-\mathrm{cm}$ Vis-C resolution and combining these new data with what was available from other sources (such as soils maps, satellite data, and light detection and ranging [lidar]-derived data).

\section{Visible Color Imagery}

The Vis-C orthophoto and resulting DSM have a $2.5-\mathrm{cm}$ GSD (based on pixel size) and serve as the base product, providing surface detail that enables identification of individual plants and cropping rows and the best representation of visible color. MS imagery can also provide a DSM, but the coarser GSD (6-cm) makes it more difficult to distinguish exposed soil from vegetation. High-resolution Vis-C data provide the best structure-from-motion product, creating a three-dimensional DSM. This DSM captures features above the surface, including buildings, trees, surface-flow paths, and the texture and detail of management features that might otherwise be confused with subsurface drainage. However, at most sites, enough of the bare-soil surface was recognizable to enable an interpretation of the topography that defines surface-water flow paths.
The high-resolution Vis-C DSM benefits from two data collections. The first flight plan captures the AOI with the sensor in the nadir position (pointing straight down at the ground). Flight lines in the second flight plan are perpendicular to the first and the sensor is approximately 20 degrees off nadir. This off-nadir flight increases depth of field and renders a more complete model of the surface. For example, if the first flight plan includes flight lines that traverse a north-south orientation, the second flight plan will include flight lines that are oriented east-west; for each set of flight lines, the aircraft collects images in both directions of flight. When anchored with ground-control points, this method provides a surface representation with a spatial accuracy relative to real-time kinematic positioning surveys (Sherwood and others, 2018).

\section{Multispectral Imagery}

Multispectral images were processed as coincident five-band imagery (table 2) so that all spectra used the same tie-points. The MS imagery has a 6-cm GSD for each of the colocated five bands, providing true-color (using R, G, B) or false color (NIR, R, G; fig. 3) imagery that is analogous to what is available from satellite imagery. These independent bands better highlight vegetation characteristics and enable calculation of the normalized difference vegetation index (NDVI):

$$
\mathrm{NDVI}=[\mathrm{NIR}-\mathrm{Red}] /[\mathrm{NIR}+\mathrm{Red}]
$$

and the normalized difference red-edge index (NDRE)

$$
\mathrm{NDRE}=\left[\mathrm{NIR}-\mathrm{R}_{\text {edge }}\right] /\left[\mathrm{NIR}+\mathrm{R}_{\text {edge }}\right]
$$

that further illustrates plant health and soil-water content (Allred and others, 2020). Healthy plants absorb blue and red wavelengths and reflect the NIR wavelengths because of 
Table 2. MicaSense RedEdge center wavelength and bandwidth (from MicaSense Inc., 2015).

[nm, nanometer; NIR, near infrared]

\begin{tabular}{lccc}
\hline $\begin{array}{r}\text { Band } \\
\text { name }\end{array}$ & $\begin{array}{c}\text { Band } \\
\text { number }\end{array}$ & $\begin{array}{c}\text { Center } \\
\text { wavelength }(\mathbf{n m})\end{array}$ & $\begin{array}{c}\text { Bandwidth } \\
\text { (nm) }\end{array}$ \\
\hline Blue & 1 & 475 & 20 \\
Green & 2 & 560 & 20 \\
Red & 3 & 668 & 10 \\
RedEdge & 5 & 717 & 10 \\
NIR & 4 & 840 & 40 \\
\hline
\end{tabular}

the presence of chlorophyll, thus rendering areas of healthy vegetation as shades of red to pink. These spectra are key to identifying tile drainage in areas with inconsistent vegetative color because where bare ground is not identifiable, plant health can indicate differences in soil-water content and drainage.

\section{Thermal Infrared Imagery}

Thermal-infrared images are single-band, 16-bit data that are effectively displayed in grayscale. TIR imagery was converted from emittance to an estimated ground-surface temperature as follows from PIX4D (2018):

$$
{ }^{\circ} \mathrm{C}=0.04 \times \mathrm{TIR}-273.15 ;
$$

where

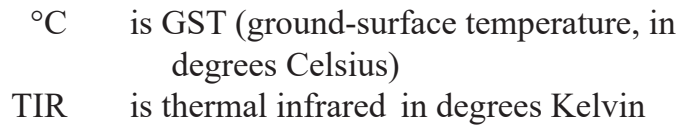

however, no calibration or ground control was used for temperature, so individual sites are characterized as "cool" to "warm." TIR imagery was captured with a GSD of $12 \mathrm{~cm}$ and highlights differences in how bare-soil surface temperature varies spatially at these agricultural sites as a function of soil-water content. Spatial variability in soil-water content is dependent on a combination of characteristics that include soil type, surface management (conservation tillage and cover crops), vegetation abundance and age, and subsurface agricultural drainage (tile drains).

\section{Analysis and Interpretation of Imagery Products}

The EOF site data-analysis workflow (fig. 4) was developed to help guide data processing and to enable the tile-drain interpretation process. For some EOF sites, all imagery products were useful, whereas for other sites, only a subset of the imagery products were helpful in interpretation.
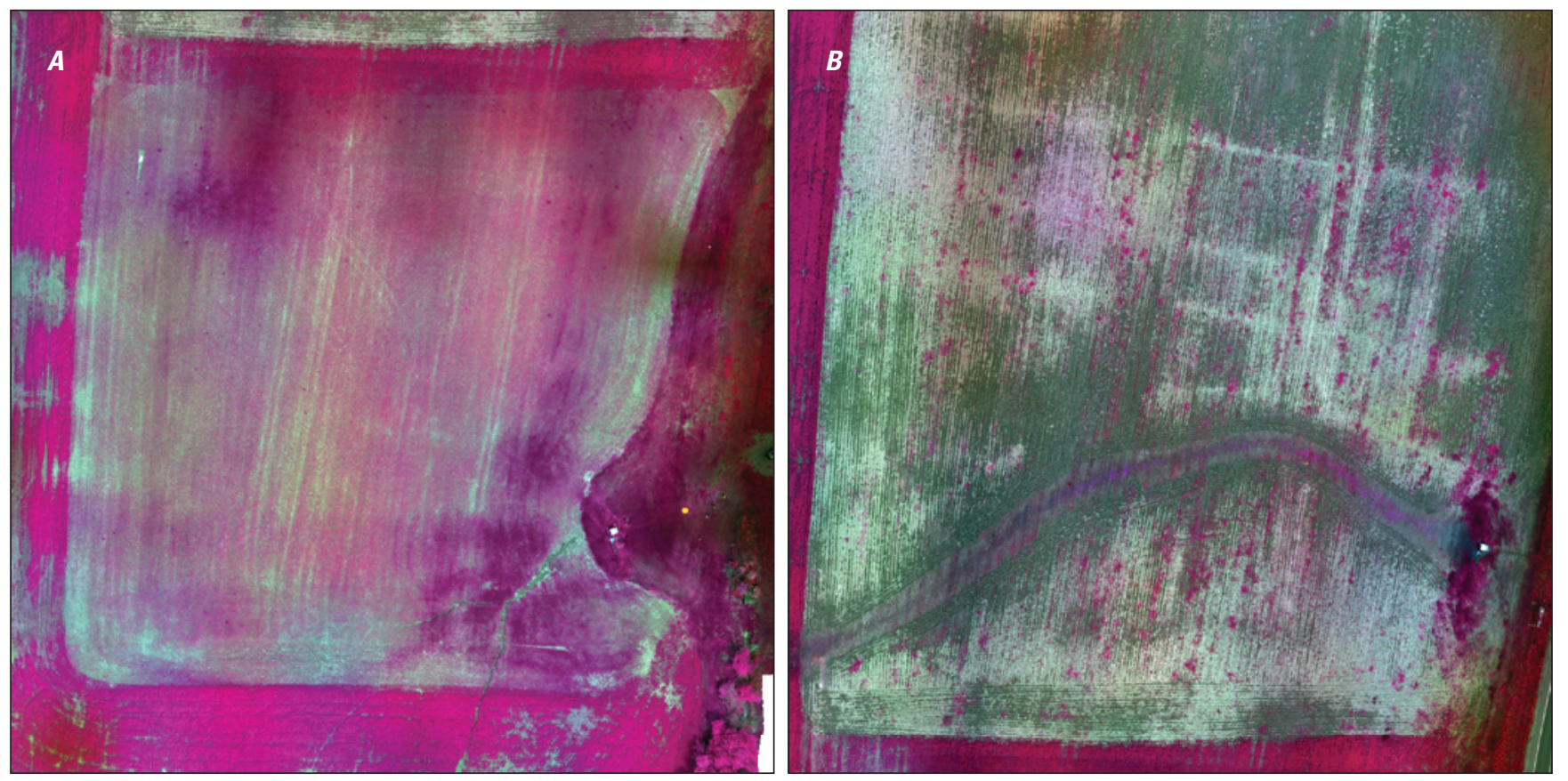

Figure 3. Multispectral imagery showing, $A$, field with cover crop and, $B$, field without cover crop. Infrared imagery is useful in illustrating plant health, soil water content, and identifying possible tile drains. 


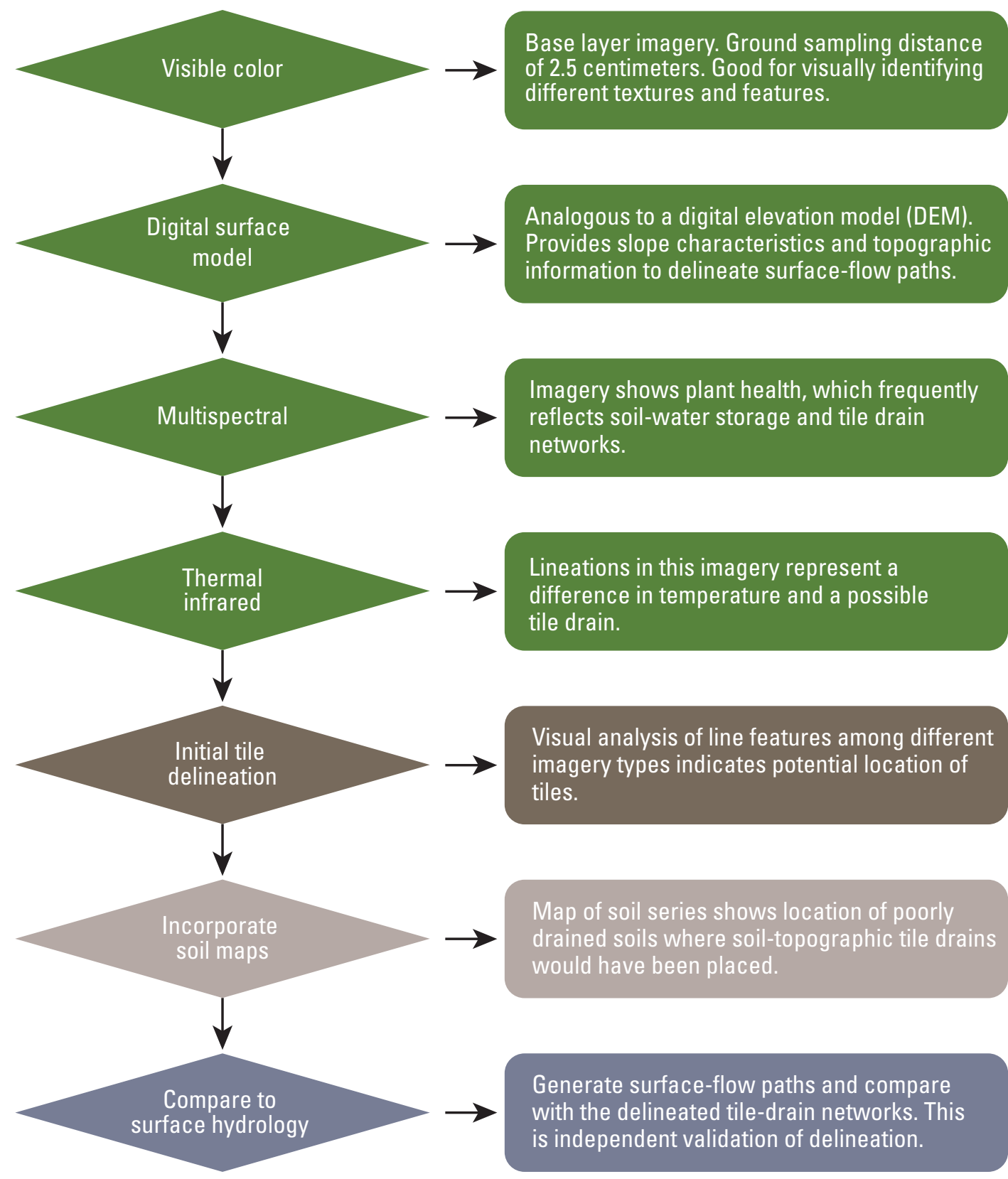

Figure 4. Edge-of-field site data-analysis workflow highlighting products and process for tile delineation.

\section{Tile-Drain Networks}

After the DSM and orthophotos were processed, the combination was used for visible interpretation of the location of tile drains (fig. 4). Vis-C orthophotos were displayed at a 35 percent transparency and overlaid upon a hillshaded DSM to enhance the ability to discern surface-flow paths from other surficial features. Soils data (U.S. Department of Agriculture - Natural Resources Conservation Service,
2020) were obtained for each site in order to understand where topographic-soil tile-drains might have been entrenched. Comparison of Vis-C, MS, and TIR imagery with the DSM helped differentiate surface features such as erosional paths and crop rows. Tile-drain networks were identified as relatively continuous line features that were discernable in multiple types of imagery, including having an identifiable link with plant health. Topographic-soil tile drain features were curvilinear and generally followed soil series classified 
as more poorly drained than the surrounding soils. Some fields had patterned tiles, which were identifiable as parallel sets of lines that intersected a "main" that would connect to the stream network. Tile-drains were digitized by hand.

\section{Contributing Area for Edge-of-Field Monitoring}

The water and nutrient budgets that are the focus of EOF monitoring are dependent on having an accurate delineation of the surface area (overland flow) and subsurface area (tile-drain discharge) from which water is being sampled. GLRI EOF sites were started over a series of years in multiple states - the result is that the contributing area for each of the sites was originally delineated from various spatial resolutions, ranging from the 10-m National Elevation Dataset as part of the USGS StreamStats application (Gesch and others, 2002; Ries III and others, 2017) to $1.5-\mathrm{m}$ lidar provided by local cooperators. In some cases, the relief at an individual EOF site is as little as $2 \mathrm{~m}$ and that of surface-water flow paths is on the order of centimeters. Consequently, the high-resolution DSMs from UAS data collection provide a better understanding of contributing area and surface hydrology than was originally available for some of these sites and a verification of contributing area at others. These DSMs highlight where field boundaries are exceeded by contributing areas, indicating that nutrient budgets may be affected by adjacent properties, and where the subsurface contributing area indicated by the tile-drain network does not align with the contributing area for surface-water monitoring.

\section{Surface-Water Flow Paths}

Delineation of surface-water flow paths helps to identify areas where tile drains would have been placed in poorly drained soils of topographic lows, a water management technique that dates back to the 1800 s. Surface-water flow paths were generated after visually interpreting inferred tile networks using the suite of Vis-C, MS, and TIR imagery. These surface-water flow paths are independent confirmation of the presence of tile-drain networks that were identifiable in these same locations. Surface-water flow paths were delineated using a series of steps (fig. 5) that included identifying the flow direction of each cell in an upscaled DSM, integrating cells as a flow-accumulation raster, converting this flow-accumulation raster to a flow-path raster using cells with greater than 100 contributing cells, and converting this flowpath raster to a line feature. Surface-water contributing areas were drawn based on these flow paths.

The $2.5-\mathrm{cm}$ resolution of the UAS DSM was too granular to delineate surface-water flow paths because it captured a mix of superficial features that obscured site topography, including farm-management and vegetation. Consequently, $2.5-\mathrm{cm}$ DSMs were upscaled (resampled to a coarser resolution) as necessary to produce a surface-water flow network that was not interrupted by these superficial features. The resulting
DSMs were resampled from a spatial resolution of $2.5 \mathrm{~cm}$ to $1.53 \mathrm{~m}$. Given the utility of upscaled DSMs for delineating surface-water flow paths, a second set of surface-water flow paths was delineated using lidar DEMs for individual sites to determine whether DSMs produced from UAS imagery provided additional information.

\section{Site-specific Information Provided by UAS Surveys}

UAS surveys were done to provide GLRI site leads with information on the location of tile-drains. Low-altitude Vis-C, MS, and TIR imagery collected during the UAS surveys are included in U. S. Geological Survey data releases for Michigan Flume 2 (Williamson and others, 2020a), Wisconsin Surface-Water 3 (Williamson and others, 2020b), Wisconsin Surface-Water 4 and 5 (Williamson and others, 2020c), and Wisconsin Bioreactor (Williamson and others, 2020d).

\section{Michigan Edge-of-Field Site}

The Michigan EOF site 2 (MI-FM2 [-TL2]; USGS Site ID 0414826504[3]; U.S. Geological Survey, 2021) discharges into a stream system that ultimately flows to Lake Huron (table 3; fig. 1). This site has been monitored since 2015 and after a baseline monitoring period of three years, a mixed cover crop and "other" BMPs were introduced. This mixed cover crop made it more difficult to use thermal imagery to identify the location of tile drains because the soil-water signature was inconsistent, possibly because of multiple plant types and nonuniform plant density (fig. 6). Given the plant density at this site and the presence of flowering plants over bare soil, the thermal product was minimally useful at this location. The contributing area for the MI-FM2 EOF site was originally estimated at 5.46 hectares (Institute of Water Research, 2014). After visual interpretation of the UAS imagery and associated products, the contributing area was estimated at 4.16 ha (approximately 25 percent less) because surface-water flow paths in the northwestern corner of the field drained northward. Surface flow paths delineated with the upscaled DSM were similar to those using 3-m lidar data. However, the surface-water flow path networks for this site that were derived from the upscaled DSM indicate that the tree-lined field boundaries on the northwestern and southern edges of the field create a topographic divide that helps define the contributing area in combination with field topography that divides the central part of the field from parts to the east and west.

A set of topographic-soil tiles were identified from the UAS imagery for the EOF site. Although visible tile extends beyond the area that contributes to what is monitored for surface runoff, tile density beneath this monitored area is estimated at $148.06 \mathrm{~m} / \mathrm{ha}$. Multiple types of imagery indicate a tile 

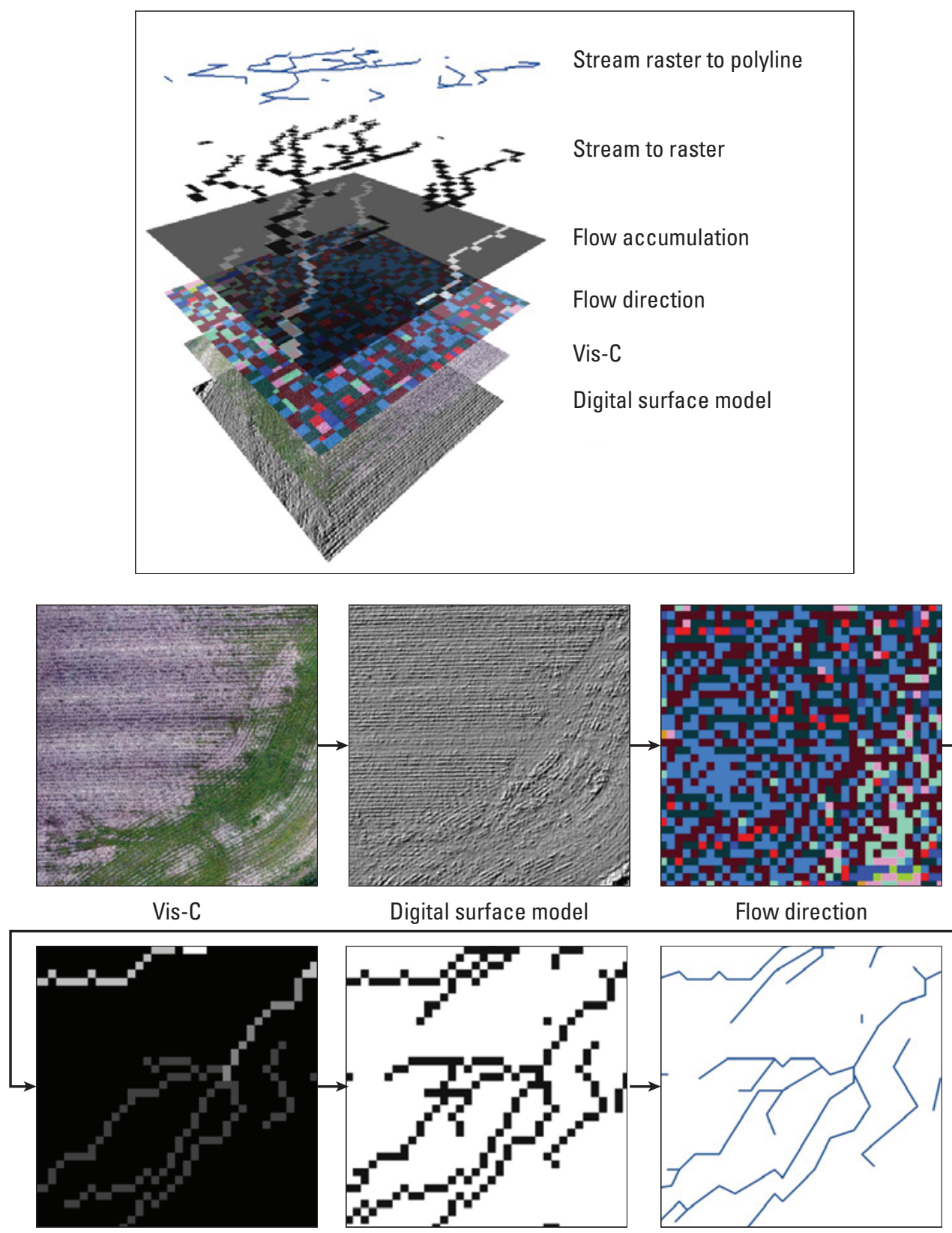

Digital surface model

Flow direction

Flow accumulation

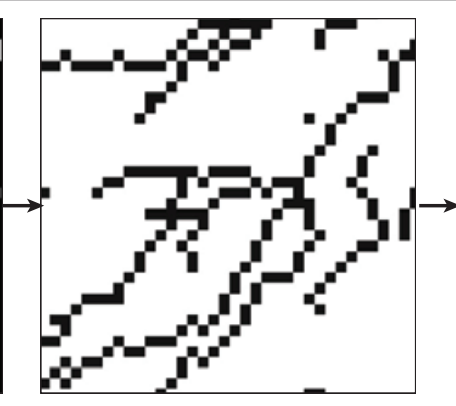

Stream to raster

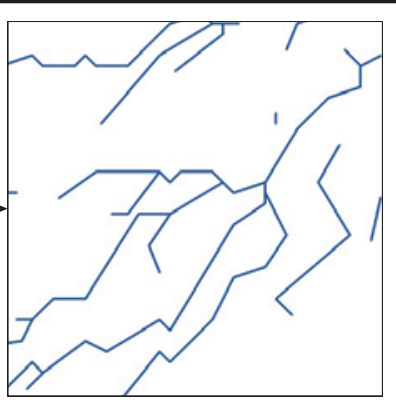

Stream raster to polyline

Figure 5. Surface hydrology delineation workflow in perspective and planer view.

Table 3. Characteristics of Michigan edge-of-field site.

[UAS, unmanned aircraft system; MI-FM2, Michigan flume 2; MI-TL2, Michigan tile 2; ha, hectares; $\mathrm{m}$, meter; $\mathrm{m} / \mathrm{ha}$, meters per hectare]

\begin{tabular}{ll}
\hline \multicolumn{1}{c}{ Site characteristics from UAS survey } & \multicolumn{1}{c}{ MI-FM2 } \\
\hline Relief of monitored area & $6 \mathrm{~m}$ \\
Surface contributing area to MI-FM2 & $4.16 \mathrm{ha}$ \\
Tile length monitored at MI-TL2 & $676.78 \mathrm{~m}$ \\
Density of tile within surface contributing area & $615.95 / 4.16=148.06 \mathrm{~m} / \mathrm{ha}$ \\
\hline
\end{tabular}




\section{A. Visible color}

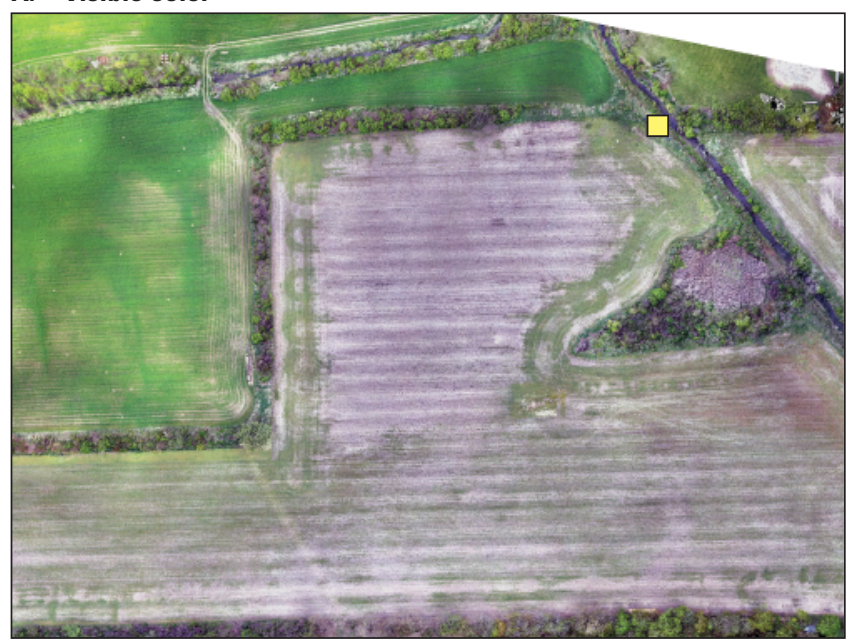

C. Multispectral, multispectral-red-green

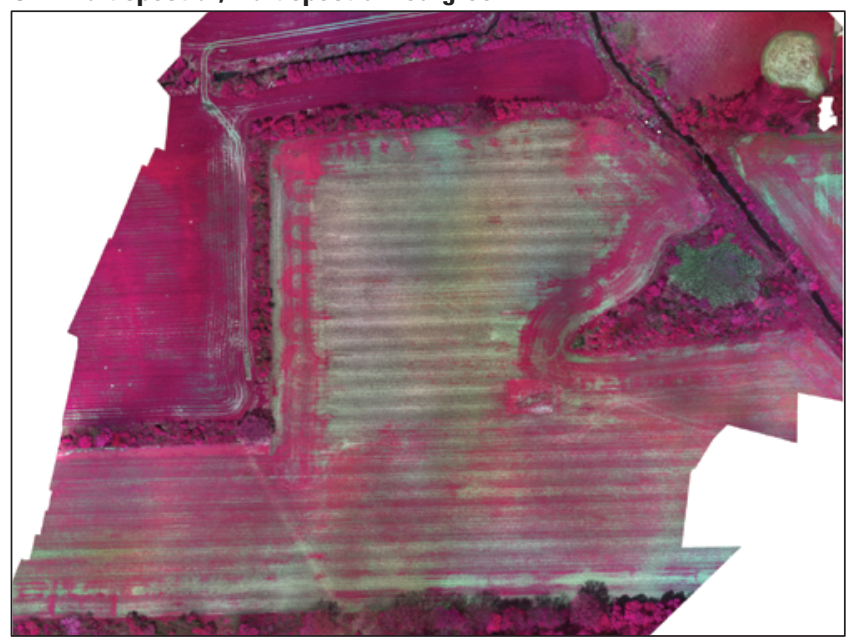

E. Delineated tiles on soil map

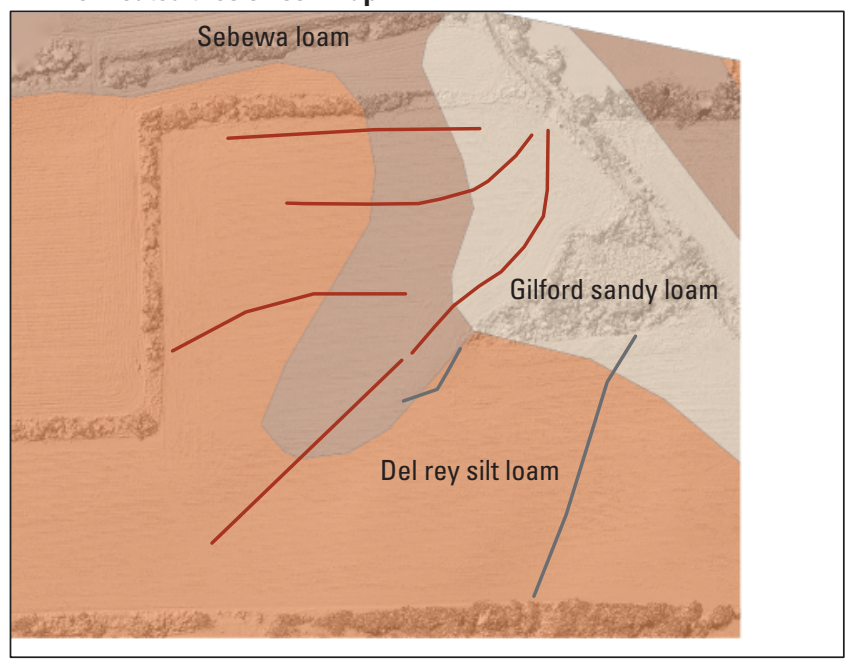

Soil maps source: U.S. Department of Agriculture Natural Resources Conservation Service

\section{B. Surface-water flow paths on digital surface model classified elevation}

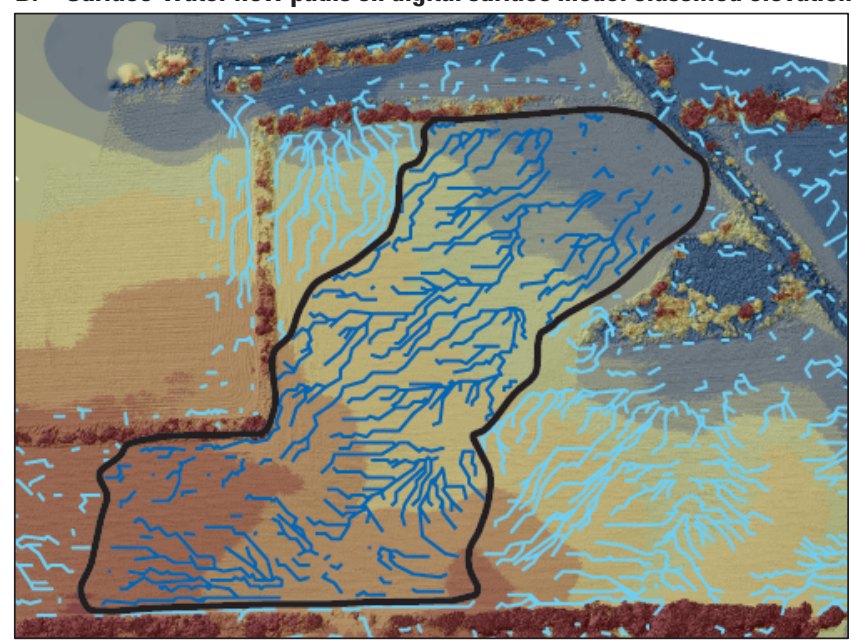

\section{Thermal infrared}
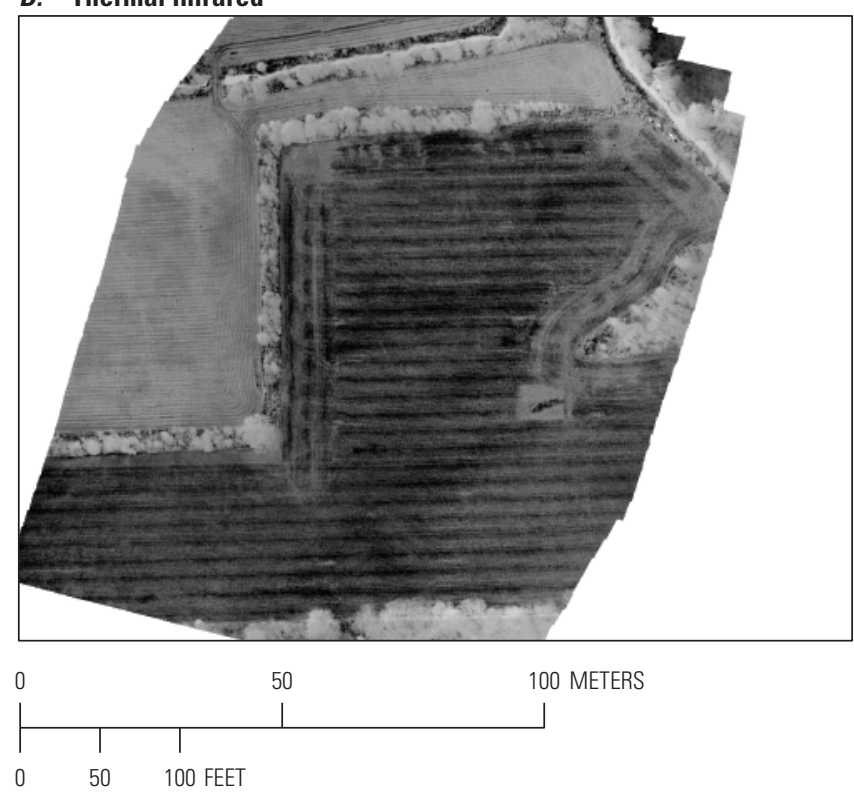

\begin{tabular}{|c|c|c|c|}
\hline \multicolumn{4}{|c|}{ EXPLANATION } \\
\hline $\boldsymbol{A}$ & $\square$ & \multicolumn{2}{|c|}{ U.S. Geological Survey monitoring site } \\
\hline B & \multicolumn{2}{|c|}{ Relief, 2-meter interval } & Contributing area \\
\hline & & $\begin{array}{l}2 \\
4 \\
6 \\
8\end{array}$ & $\begin{array}{l}\text { Contributing } \\
\text { surface-water flow }\end{array}$ \\
\hline & & $\begin{array}{l}10 \\
10 \\
12\end{array}$ & $\begin{array}{l}\text { Noncontributing } \\
\text { surface-water flow }\end{array}$ \\
\hline \multirow{2}{*}{ D } & & Warm & \\
\hline & & & \\
\hline \multirow[t]{2}{*}{$\boldsymbol{E}$} & - & \multirow{2}{*}{\multicolumn{2}{|c|}{$\begin{array}{l}\text { Tile interacting with monitored area } \\
\text { Tile outside contributing area }\end{array}$}} \\
\hline & - & & \\
\hline
\end{tabular}

Figure 6. $A, C, D$, Michigan flume 2 (MI-FM2) and tile-drain 2 (MI-TL2) imagery, $B$, digital surface model derived from visible-color imagery, and, $E$, interpreted surface-water flow paths, and interpreted tile-drain locations overlain on a combination of visible-color imagery and soil series boundaries. These two monitoring sites are colocated. 
drain that discharges into the swale that is outside of the contributing area; however, the site lead had already investigated, and no tile outlet was found. The uncertainty of the tile-drain extent and connectivity at this site warrant further investigation by other means or a time-series of imagery focused on a large storm while the soil is relatively exposed (Allred and others, 2020). Low-altitude Vis-C, MS, and TIR imagery collected at the Michigan site 2 are available as a USGS data release (Williamson and others, 2021a).

\section{Wisconsin Edge-of-Monitoring Sites}

All three Wisconsin sites drain to streams that discharge into Green Bay and Lake Michigan. Surface-water 3, 4, and 5 are situated in Brown County and the Bioreactor site is located on the southeastern part of Green Bay in Door County (fig. 1).

\section{Wisconsin Surface Water 3 and Tile 1}

Monitoring at Wisconsin surface-water site 3 (WI-SW3 [-TL1]; USGS Site ID 441520088045001[2]; U.S. Geological Survey, 2021) began in 2014, with introduction of the BMPs of conservation tillage and cover crop in 2016. This site has rolling topography, with $8 \mathrm{~m}$ of relief between the highest point of the drainage divide and the gaged outlet; this is the most relief among the EOF sites surveyed (fig. 7). The UASderived tile-drain network closely matched a sketch that was provided by the landowner, validating this UAS methodology. Flow networks were generated using a UAS DSM that was upscaled to $1.53-\mathrm{m}$ spatial resolution from the original $2.5-\mathrm{cm}$ resolution. The UAS survey confirmed that the area underlain by the monitored tile (WI-TL1) is more than twice the area contributing surface water to WI-SW3 (table 4). Tile density beneath the monitored surface-contributing area is estimated at $167.20 \mathrm{~m} / \mathrm{ha}$. Low-altitude Vis-C, MS, and TIR imagery collected at the Wisconsin surface-water site 3 are available as a USGS data release (Williamson and others, 2021b).

\section{Wisconsin Surface-Water Sites 4 and 5}

Surface-water EOF sites 4 and 5 (WI-SW4 [USGS Site ID 442119088085501 ] and WI-SW5 [USGS Site ID 442114088085701]; U.S. Geological Survey, 2021) are paired fields that have been monitored since 2015 (fig. 8; table 5). The tile drain was not being monitored at the time of the UAS survey. Management of the southern field (WI-SW5) incorporated a combination of conservation tillage and cover crops as BMPs beginning in 2017; WI-SW4 was left as a control. While the fields are separated by only a small vegetation berm, the $2.5-\mathrm{cm}$ DSM showed that the contributing areas of the two monitored areas are separated by 1.20 ha that is not captured by either monitoring site (referred to here as "unmonitored"). The surface-water flow path analysis indicates that water from this unmonitored area flows in front of the WISW5 site and south along the road where it combines with discharge from the monitored areas.

The area flown was designed to capture the entirety of both fields - not just the contributing areas. Similarities in the surface-flow patterns on the monitored fields, relative to those on the adjacent fields to the west and south, indicate that surface water on these fields flowed to the west and to the south perhaps as recently as 2011 (Google Earth, 2020). This interpretation is supported by the apparent location of older soil-topographic tiles that have been supplemented by densely patterned tiles, and field management that is recognizable in historical air photos that predate the EOF study design. As observed in the previous sites, WI-SW4 and WI-SW5 are drained by tiles that extend beyond the area that is being monitored for surface runoff. WI-SW4 is drained by a more densely patterned tile system than WI-SW5.

Because of the combination of the constructed field berms and the apparently redefined surface-flow direction, generating flow paths with the UAS DSM was difficult for this site. This indicates that an AOI for which the surface roughness is similar to the relief of the drainage divide makes it difficult to identify contributing area, even when using a DSM. For example, the western boundary of each of these surface-water sites is defined by relief on the order of $0.1 \mathrm{~m}$, similar to that seen along planting rows. Low-altitude Vis-C, MS, and TIR imagery collected at Wisconsin surface-water sites 4 and 5 are available as a USGS data release (Williamson and others, 2021c).

\section{Wisconsin Bioreactor}

Construction and monitoring of the Wisconsin bioreactor began in 2018. This site is in southwestern Door County. New tile-drain installation as part of bioreactor construction at this site provided a map of subsurface drainage that was installed in 2013 (fig. 9) to purposely drain the northeast corner of the field. This drainage includes a fanned network of tiles that drain to a single lateral tile and are spaced approximately 1-3 $\mathrm{m}$ apart. This lateral then joins a herringbone pattern that drains via a "main" to a large culvert and surface-water drainage on the western edge of the field. Part of the flow from this main is directed to the bioreactor (fig. 10). Consequently, learning more about older tile-drain systems and peripheral systems that might be affecting overland and subsurface flow around the bioreactor was the rationale for acquiring imagery at this site. Low-altitude Vis-C, MS, and TIR imagery collected at the Wisconsin bioreactor site are available as a USGS data release (Williamson and others, 2021d).

Image collection for this site also provided an opportunity to assess plant health as an indicator of subsurface water management by focusing on the variability in cover crop (alfalfa) appearance in the northeast corner of the field. The flight area for this site was designed to capture the quarter 


\section{A. Visible color}

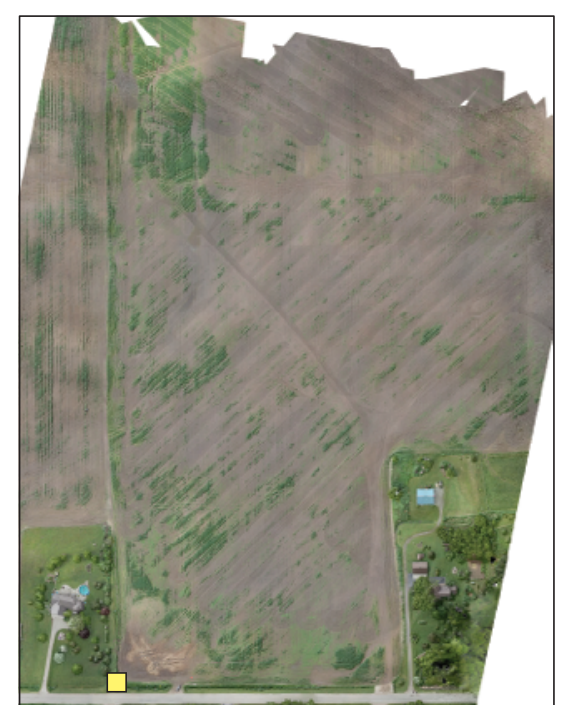

D. Thermal infrared

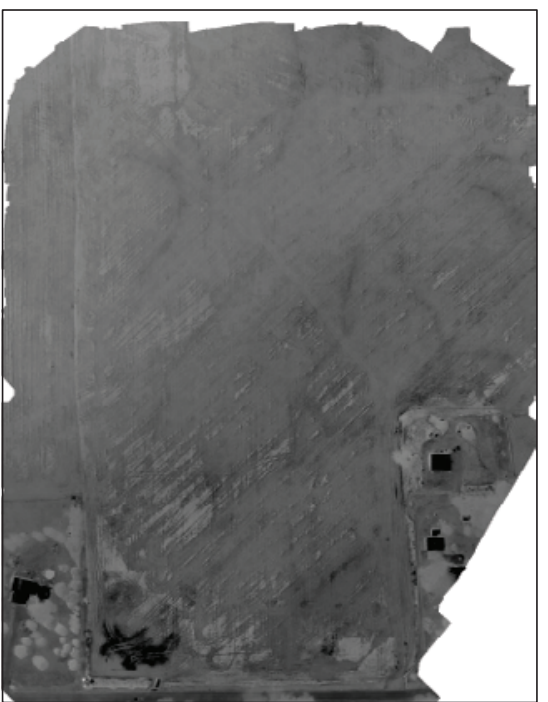

100 METERS

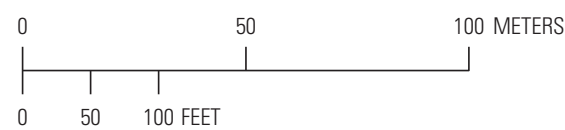

B. Surface-water flow paths on digital surface model classified elevation

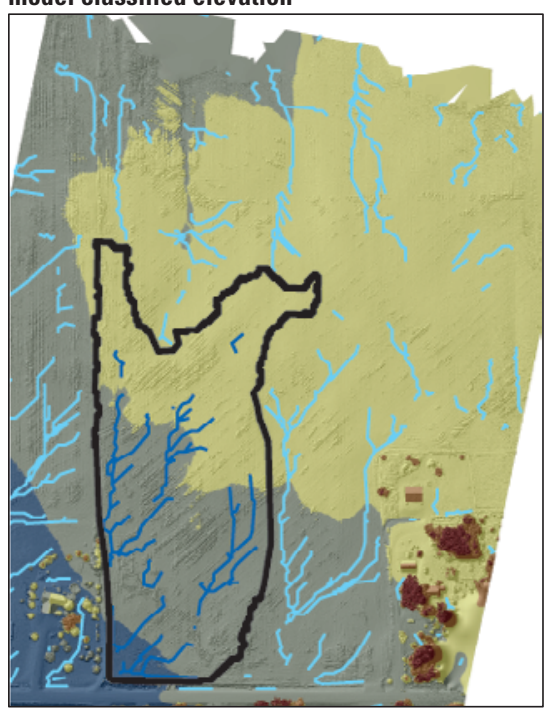

E. Delineated tiles on soil map

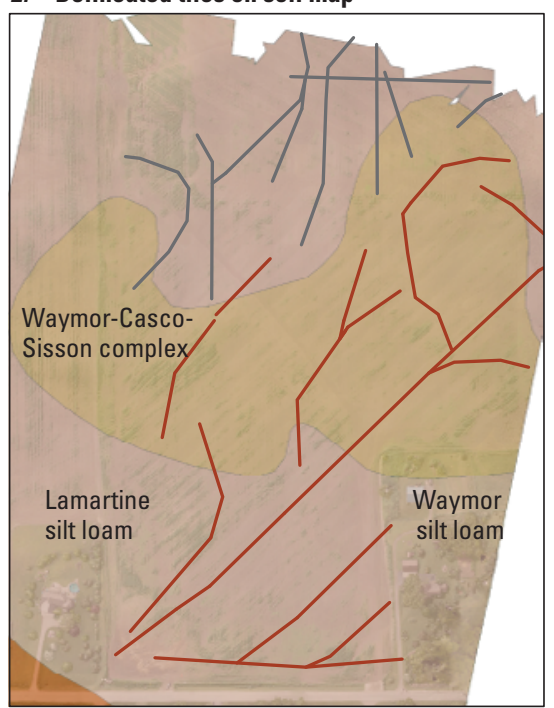

Soil maps source: U.S. Department of Agriculture Natural Resources Conservation Service

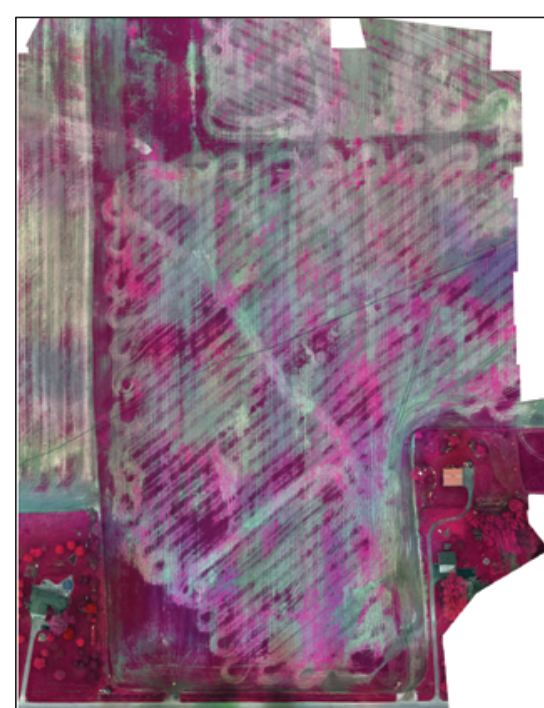

\section{EXPLANATION}

A $\quad \square \quad$ U.S. Geological Survey monitoring site

B Relief, 2-meter interval

Contributing area

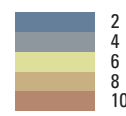

Contributing

surface-flow

Noncontributing

Warm

- Coo

$E \quad$ Tile interacting with monitored area

Tile outside contributing area

Figure 7. $A, C, D$, Wisconsin surface-water 3 (WI-SW3) and tile-drain 1 (WI-TL1) imagery, $B$, digital surface model derived from visible-color imagery, and interpreted surface-water flow paths, and, $E$, interpreted tile-drain locations overlain on a combination of visible-color imagery and soil series boundaries. These two monitoring sites are colocated. 
Table 4. Characteristics of Wisconsin surface-water 3 and tile drain 1.

[WI-SW3, Wisconsin surface water 3; WI-TL1, Wisconsin tile drain 1; ha, hectares; UAS, unmanned aircraft system; m, meter; m/ha, meters per hectare]

\begin{tabular}{ll}
\hline \multicolumn{1}{c}{ Site characteristics from UAS survey } & WI-SW3 \\
\hline Relief of monitored area & $8 \mathrm{~m}$ \\
Surface contributing area to WI-SW3 & $2.86 \mathrm{ha}$ \\
Tile length monitored at WI-TL1 & $1637.80 \mathrm{~m}$ \\
Density of tile within surface contributing area & $478.22 / 2.86=167.20 \mathrm{~m} / \mathrm{ha}$ \\
\hline
\end{tabular}

section (1/4 square mile; 65 hectares) shown in (fig. 9). The newly installed tile system drains the northeast quarter of this $\mathrm{AOI}$ and drains west to the bioreactor.

Although the same workflow was completed for this site, the density and generally consistent appearance of the cover crop prevented delineation of any patterned-tile networks from the UAS imagery. Bare soil was rarely exposed at this site, so the dense cover crop was interpreted to reflect surface topography. Based on a combination of plant health, as evidenced from multiple types of imagery, with the location of a grassed waterway, topographic-soil tile drains were delineated, and the appropriateness of these tile-drain locations were interpreted using surface-water flow path networks combined with the soil map.

Three factors explain why the bioreactor is receiving more water than the designed environment (fig. 9)

1. The general hydrologic gradient is to the northwest and surface-water and tile-drain discharge converge on the large culvert that is identifiable immediately south of the bioreactor, where the field-access road intersects the paved county road. This large culvert also receives drainage from an apparent tile-drain that is fed by the road-ditch on the southeast edge of the field.

2. The contributing area for the field extends beyond the field boundary to the east. Consequently, the newly installed tile-drain system is likely draining soil water from the adjacent field. To supplement the UAS imagery, the 2018 Door County lidar DEM, with a resolution of $1 \mathrm{~m}$ (Wisconsin View, 2019), was also used to delineate surface-water flow paths. However, this lidar ends at the county line to the south of the image, so it also failed to capture the entire drainage network.

3. There is evidence that this site has a topographic tile set with a density similar to FM2 and SW3 that further connects the northeast portion of the field to the upslope area to the east. This topographic-soil tile network was likely in place before the new patterned tile system was installed.

\section{Limitations of Approach}

Site-specific surveys of GLRI EOF monitoring sites included contemporaneous Vis-C, MS, and TIR imagery. Together, this imagery enabled delineation of likely tile-drain networks at sites where bare soil was identifiable, highlighted when surface contributing areas did not align with that being managed by subsurface drainage, and provided refined estimates of contributing area for some of the sites. The delineated tile-drain networks are based on features that are coincident in multiple products from these UAS surveys, including linear patterns in plant abundance and health and (or) soil-surface temperature. Because each of these sites is being monitored for water quality, it was essential to identify a method of delineating tile drains that did not physically disturb the soil. Consequently, no attempt was made to physically confirm the extent of these tile-drain networks. Previous research has validated similar UAS surveys by collecting data at sites with preexisting maps or by using ground-penetrating radar (Williamson and others, 2019; Allred and others, 2020). However, tile-drain extent and characteristics were not available for all sites and surveying entire sites with ground-penetrating radar is time prohibitive. Instead, other methods were used to confirm the tile-drain locations, including the distribution of soil series, the ability to follow delineated tile-drain networks to known tile-drain discharge points, and similarity to sketches provided by landowners (WI-SW3). However, there is the potential that some features were interpreted as tile drains that are not and that some tile drains were not captured by the survey. Any misinterpretation in these tile delineations may cause error in the extent of individual tile-drain lines but are expected to minimally affect the estimate of area undergoing subsurface drainage and does not affect estimates of contributing area for overland flow. Additionally, the type of tile-drain network present at each site - topographic-soil versus densely patterned-is no longer in question. This also provides information about the potential age and material of individual tile-drain networks. 


\section{A. Visible color}

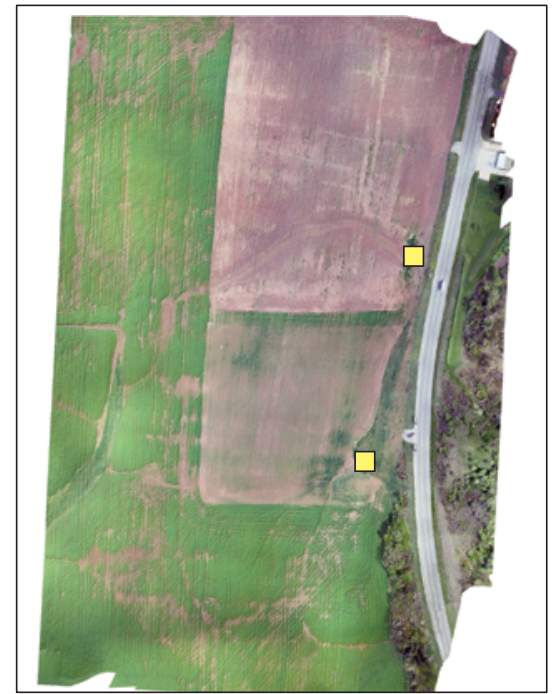

D. Thermal infrared

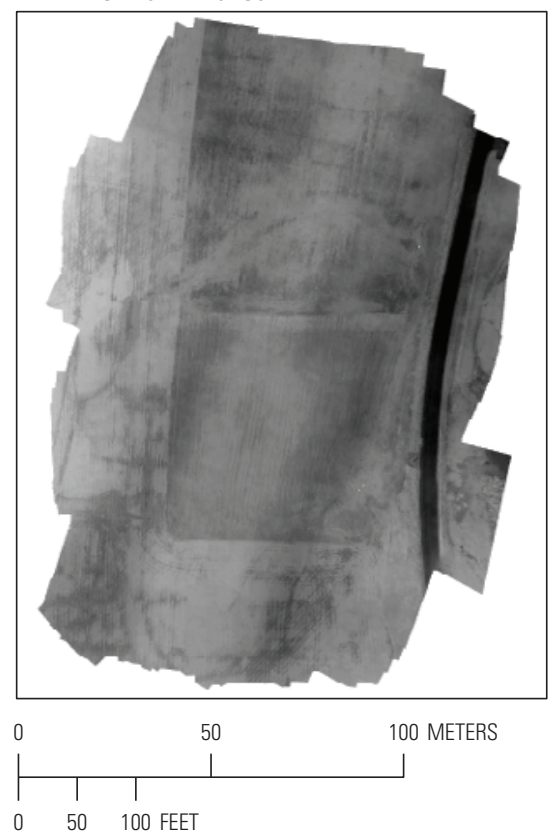

B. Surface-water flow paths on digital surface model classified elevation

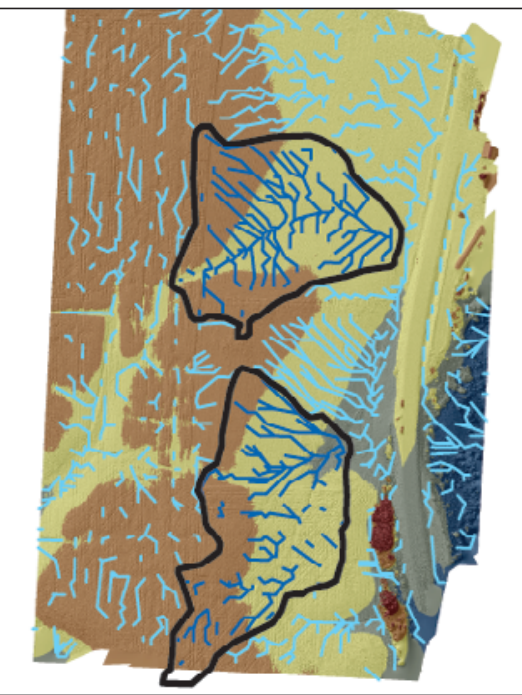

\section{E. Delineated tiles on soil map}

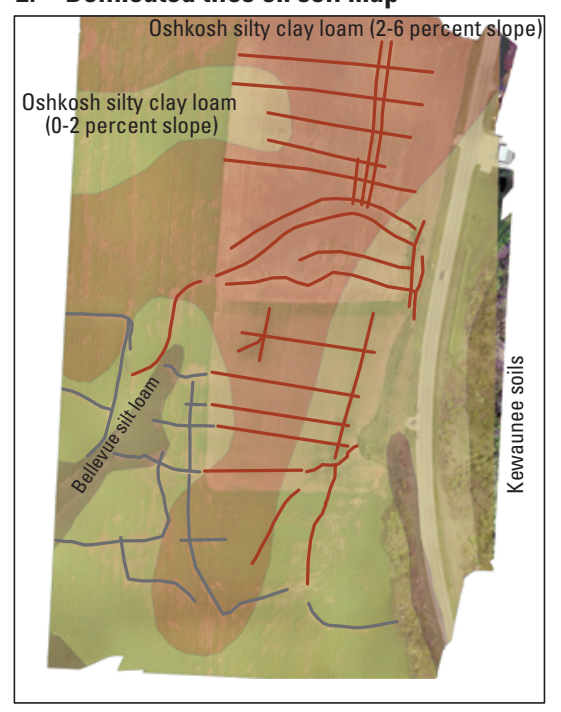

Soil maps source: U.S. Department of Agriculture Natural Resources Conservation Service
C. Multispectral, near infrared-red-green

$\vec{D}$

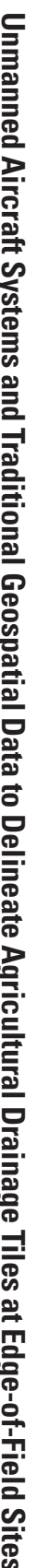

\section{EXPLANATION \\ A $\square \quad$ U.S. Geological Survey monitoring site}

B Relief, 4-meter interval

Contributing surface-water flow

Noncontributing surface-waterflow

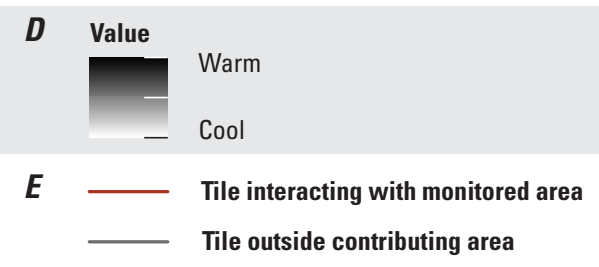

E _ Tile interacting with monitored area

Figure 8. $A, C, D$, Wisconsin surface water 4 and 5 (WI-SW4, SW5) imagery, $B$, digital surface model derived from visible-color imagery, and, $E$, interpreted surface flow paths, and interpreted tile-drain locations overlain on a combination of visible-color imagery and soil series boundaries. 
Table 5. Characteristics of Wisconsin surface-water sites 4 and 5.

[WI-SW4, Wisconsin surface water 4; WI-SW5, Wisconsin surface water 5; ha, hectares; UAS, unmanned aircraft system; m, meter; m/ha, meters per hectare]

\begin{tabular}{lll}
\hline \multicolumn{1}{c}{ Site characteristics from UAS survey } & \multicolumn{1}{c}{ WI-SW4 } & \multicolumn{1}{c}{ WI-SW5 } \\
\hline Relief of monitored area & $3 \mathrm{~m}$ & $4 \mathrm{~m}$ \\
Surface contributing area & $4.74 \mathrm{ha}$ & $5.07 \mathrm{ha}$ \\
Tile length discerned under fields & $1950.52 \mathrm{~m}$ & $1759.54 \mathrm{~m}$ \\
Density of tile within surface contributing area & $878.00 / 4.74=185.23 \mathrm{~m} / \mathrm{ha}$ & $598.82 / 5.07=118.11 \mathrm{~m} / \mathrm{ha}$ \\
Minimum spacing of parallel tile-drains & $5.47 \mathrm{~m}$ & $16.21 \mathrm{~m}$ \\
\hline
\end{tabular}

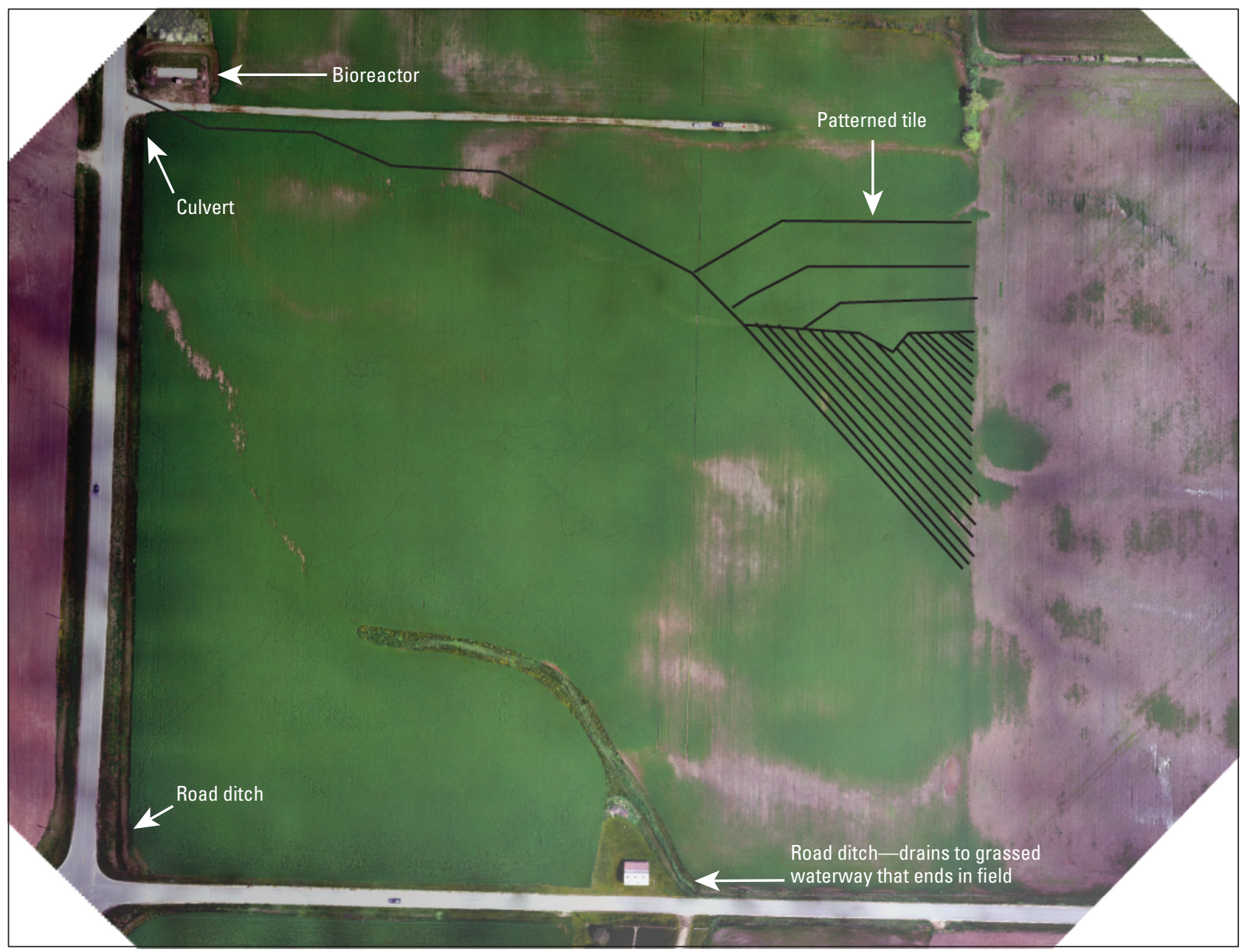

Figure 9. Wisconsin bioreactor site features including bioreactor location, culvert, and road ditches. 


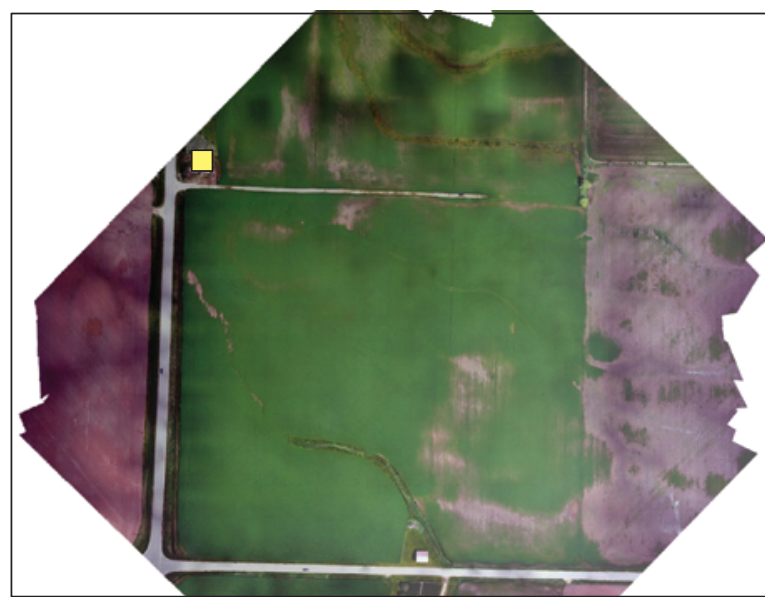

B. Surface-water flow paths on digital surface model classified elevation

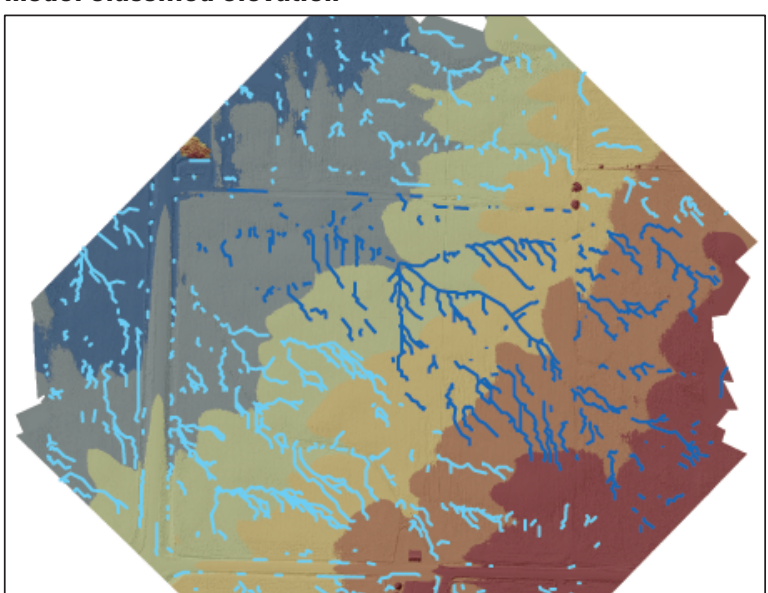

D. Thermal infrared

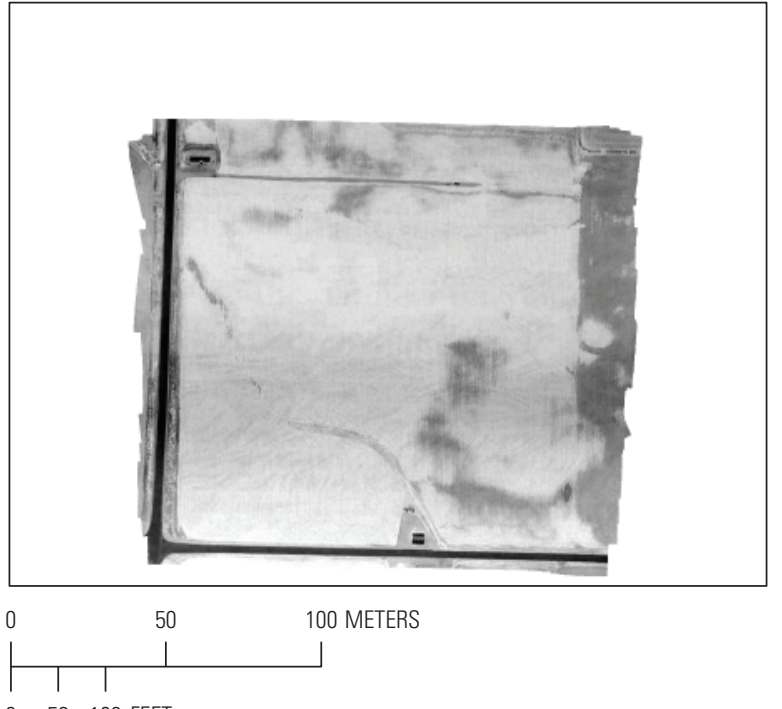

E. Delineated tiles on soil map

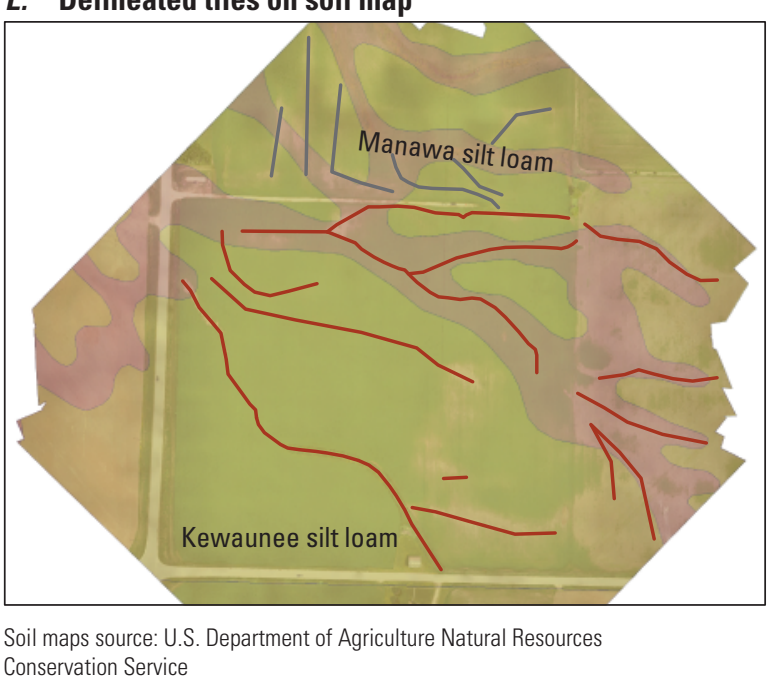

C. Multispectral, near infrared-red-green
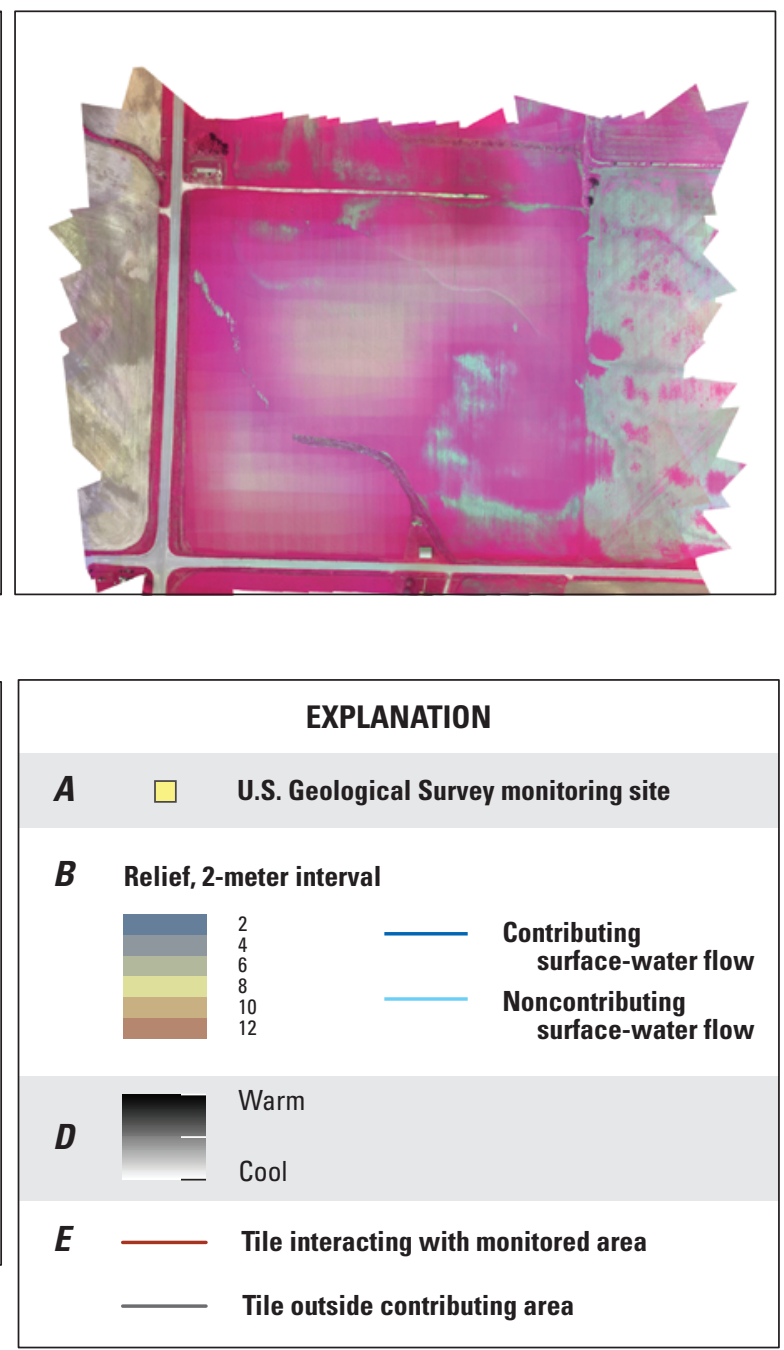

$0 \quad 50 \quad 100$ FEET

Figure 10. $A, C, D$, Wisconsin bioreactor imagery, $B$, digital surface model derived from visible-color imagery, and, $E$, interpreted surface-water flow paths, and interpreted tile-drain locations overlain on a combination of visible-color imagery and soil series boundaries. 


\section{Summary}

A critical measure of best management practice implementation is quantifying the change in water-quantity and quality leaving agricultural fields as a function of how they are managed. An accurate characterization of the field being monitored, including total area, relation between surface and subsurface drainage, and connectivity to adjacent properties, is key to an accurate budget of what water and nutrients are entering the system versus what is discharged from the system. Unmanned aircraft system surveys were conducted at four edge of field locations to better characterize these factors, including refined estimates of contributing area to surface and tile-drain monitoring sites and the extent and type of tile-drain network at each site. These surveys were conducted April-June 2019 at edge-of-field sites that are monitored in cooperation with Great Lakes Research Initiative. This information will enable more accurate accountings of precipitation and resulting runoff volume in addition to the loads of sediment and nutrients that are leaving each site. The result will be an improved ability to quantify the potential benefit of best management practice implementation on water quality in and around the Great Lakes and can be applied to study areas at different locations.

\section{References Cited}

Allred, B., Martinez, L., Fessehazion, M.K., Rouse, G., Williamson, T.N., Wishart, D., Koganti, T., Freeland, R., Eash, N., Batschelet, A., and Featheringill, R., 2020, Overall results and key findings on the use of UAV visible-color, multispectral, and thermal infrared imagery to map agricultural drainage pipes: Agricultural Water Management, v. 232, p. 106036.

Baker, D.B., Johnson, L.T., Confesor, R.B., Jr., Crumrine, J.P., Guo, T., and Manning, N.F., 2019, Needed-Earlyterm adjustments for Lake Erie phosphorus target loads to address western basin cyanobacterial blooms: Journal of Great Lakes Research, v. 45, no. 2, p. 203-211.

Gesch, D., Oimoen, M., Greenlee, S., Nelson, C., Steuck, M., and Tyler, D., 2002, The National Elevation Dataset: Photogrammetric Engineering and Remote Sensing, v. 68, no. 1, p. 5-11.

Gökkaya, K., Budhathoki, M., Christopher, S.F., Hanrahan, B.R., and Tank, J.L., 2017, Subsurface tile drained area detection using GIS and remote sensing in an agricultural watershed: Ecological Engineering, v. 108, part B, p. $370-379$.
Google Earth, 2015, Wisconsin - Surface Water 4 and 5, $44.354310 \mathrm{~N}, 88.150198 \mathrm{~W}$, Eye alt 1.19 kilometers: Google Earth web page, accessed February 7, 2020, at https://www.google.com/earth/.

Institute of Water Research, 2014, ELUCID (Environmental Learning Using Computer Interactive Decisions): Flint River Watershed, Michigan State University, accessed February 20, 2020, at http://ewatershed.iwr.msu.edu/flint/ FRWDSSS0R.html.

Lemke, A.M., Kirkham, K.G., Lindenbaum, T.T., Herbert, M.E., Tear, T.H., Perry, W.L., and Herkert, J.R., 2011, Evaluating agricultural best management practices in tile-drained subwatersheds of the Mackinaw River, Illinois: Journal of Environmental Quality, v. 40, no. 4, p. $1215-1228$.

Matthews, N., Noble, T., and Breithaupt, B., 2016, Closerange photogrammetry for 3-D ichnology-The basics of photogrammetric ichnology, in Falkingham, P.L., Marty, D., and Richter, A., eds., Dinosaur Tracks: Bloomington, Ind., Indiana University Press, p. 29-55.

MicaSense Inc, 2015, RedEdge User Manual: MicaSense web page, accessed October 20, 2020, at https://support.mica sense.com/hc/en-us/articles/215261448-RedEdge-UserManual-PDF-Download.

PIX4D, 2018, Processing Thermal Images: PIX4D web page, accessed October 20, 2020, at https://support.pix 4d.com/hc/ en-us/articles/360000173463-Processing-thermal-images.

Red River Retention Authority - Basin Technical and Scientific Advisory Committee [RRRA-BTSAC], 2011, Impacts of subsurface agricultural drainage on watershed peak flows: RRRA-BTSAC Briefing Paper, no. 1, p. 1-11.

Ries, K.G., III, Newson, J.K., Smith, M.J., Guthrie, J.D., Steeves, P.A., Haluska, T.L., Kolb, K.R., Thompson, R.F., Santoro, R.D., and Vraga, H.W., 2017, StreamStats, version 4: U.S. Geological Survey Fact 2017-3046, 4 p. [Also available at https://doi.org/10.3133/fs20173046].

Schilling, K.E., and Helmers, M., 2008, Effects of subsurface drainage tiles on streamflow in Iowa agricultural watersheds-Exploratory hydrograph analysis: Hydrological Processes, v. 22, no. 23, p. 4497-4506.

Schottler, S.P., Ulrich, J., Belmont, P., Moore, R., Lauer, J.W., Engstrom, D.R., and Almendinger, J.E., 2014, Twentieth century agricultural drainage creates more erosive rivers: Hydrological Processes, v. 28, no. 4, p. 1951-1961.

Sherwood, C.R., Warrick, J.A., Hill, A.D., Ritchie, A.C., Andrews, B.D., and Plant, N.G., 2018, Rapid, remote assessment of Hurricane Matthew impacts using fourdimensional structure-from-motion photogrammetry: Journal of Coastal Research, v. 34, no. 6, p. 1303-1316. 
U.S. Department of Agriculture Natural Resources Conservation Service, 2020, Web soil survey - SSURGO: Natural Resources Conservation Service, United States Department of Agriculture, accessed November 2, 2019, at https://websoilsurvey.nrcs.usda.gov/.

U.S. Department of Interior, 2021, Operational Procedures Memorandum (OPM)-11-Use of Unmanned Aircraft Systems (UAS), Office of Aviation Services: UAS web page, accessed February 5, 2021, at https://www.doi.gov/ node/17271.

U.S. Geological Survey, 2021, USGS water data for the Nation: U.S. Geological Survey National Water Information System database, accessed February 5, 2021, at https://doi.org/10.5066/F7P55KJN.

Westoby, M.J., Brasington, J., Glasser, N.F., Hambrey, M.J., and Reynolds, J.M., 2012, Structure-from-motion photogrammetry-A low-cost, effective tool for geoscience applications: Geomorphology, v. 179, p. 300-314.

Williamson, T.N., Dobrowolski, E.G., Meyer, S.M., Frey, J.W., and Allred, B.J., 2019, Delineation of tile-drain networks using thermal and multispectral imagery-Implications for water quantity and quality differences from paired edge-offield sites: Journal of Soil and Water Conservation, v. 74, no. 1, p. 1-11.

Williamson, T.N., Webber, J.J., and Hoefling, D.J., 2021a, Low-altitude visible, multispectral, and thermal-infrared imagery from edge-of-field monitoring sites for Great Lakes Restoration Initiative - Michigan Flume 2: U.S. Geological Survey data release, https://doi.org/10.5066/P9EXXX2O.
Williamson, T.N., Webber, J.J., and Hoefling, D.J., 2021b, Low-altitude visible, multispectral, and thermal-infrared imagery from edge-of-field monitoring sites for Great Lakes Restoration Initiative - Wisconsin Surface Water 3: U.S. Geological Survey data release, https://doi.org/ 10.5066/P9N8ELYZ.

Williamson, T.N., Webber, J.J., and Hoefling, D.J., 2021c, Low-altitude visible, multispectral, and thermal-infrared imagery from edge-of-field monitoring sites for Great Lakes Restoration Initiative - Wisconsin Surface Water 4 and 5: U.S. Geological Survey data release, https://doi.org/ 10.5066/P9DNURMT.

Williamson, T.N., Webber, J.J., and Hoefling, D.J., 2021d, Low-altitude visible, multispectral, and thermalinfrared imagery from edge-of-field monitoring sites for Great Lakes Restoration Initiative - Wisconsin Bioreactor: U.S. Geological Survey data release, https://doi.org/ 10.5066/P93R270D.

Wisconsin View, 2019, Brown County lidar dataset download, accessed December 16, 2019, at http://relief.ersc.wisc.edu/ wisconsinview/session3.php.

Zucker, L.A., and Brown, L.C., 1998, Agricultural drainageWater quality impacts and subsurface drainage studies in the Midwest: Ohio State University Extension Bulletin 871, 40 p. 
For additional information contact:

Director, USGS Ohio-Kentucky-Indiana Water Science Center U.S. Geological Survey

5957 Lakeside Boulevard

Indianapolis, IN 46278

317-290-3333

For additional information, visit: https://www.usgs.gov/centers/okiwater

Publishing support provided by the Indianapolis Publishing Service Center 
